\title{
Turning Qualitative into Quantitative Evidence: A Well-Used Method Made Explicit
}

\author{
A. W. Carus and Sheilagh Ogilvie
}

March 2005

CWPE 0512

Not to be quoted without permission 


\title{
Turning Qualitative into Quantitative Evidence: A Well-Used Method Made Explicit
}

\author{
A.W. Carus (University of Chicago) \\ Sheilagh Ogilvie (University of Cambridge)
}

Abstract: Many historians now reject quantitative methods as inappropriate to understanding past societies. It is argued here, however, that no sharp distinction between qualitative and quantitative concepts can be drawn, as almost any concept used to describe a past society is implicitly quantitative. Many recent advances in understanding have been achieved by deriving quantitative evidence from qualitative evidence, and using it jointly and dialectically with the qualitative evidence from which it is derived. Its reliability as quantitative evidence can be improved by indexing it against other quantitative evidence from the same community or population during the same period. We suggest that this triangulation method can be extended to many apparently qualitative types of sources that have not previously been used in this way. The potential of turning qualitative into quantitative evidence, then, despite its successes over the past decades, has hardly begun to be exploited.

JEL Classifications:

Keywords:
A12, B40, C10, C80, J10, N01, N30, N90

quantitative methods; qualitative methods; methodology; economic history; local studies; case studies; cliometrics 


\title{
Turning Qualitative into Quantitative Evidence: A Well-Used Method Made Explicit
}

\author{
A.W. Carus (University of Chicago) \\ Sheilagh Ogilvie (University of Cambridge)
}

Social and economic historians live uncomfortably these days. They are under pressure from two opposed sides. On the one side are economists, who want everything formalized and have little time for any but quantitative evidence (preferably very large, homogeneous data sets). And on the other side is the historical profession, which increasingly rejects quantitative methods altogether. How to mediate between these hostile and mutually uncomprehending tribes?

These present struggles recapitulate earlier ones, particularly the series of interlocking confrontations in the late nineteenth century over the appropriate method of the social sciences, among (mainly German-speaking) philosophers, economists, historians, psychologists, and other interested parties. ${ }^{1}$ These quarrels were never resolved in a clear-cut, mutually accepted concordat, but they did issue, by the early decades of the twentieth century, in Max Weber's programme for a social science, which not only tried to mediate among the warring parties, but seemed even to have achieved a kind of synthesis among them. ${ }^{2}$ Many recognized it as a framework for "the unification of the cultural and social sciences", 3 and thus in particular for the joint and mutually informative use of qualitative and quantitative evidence. Priority was given to impersonal social and economic processes as default explanations, in Weber's synthesis, and these processes could be studied in an objective, quasiscientific way. This part of his view represented the inheritance from Marx and economists such as Carl Menger. But Weber not only left room for holistic, qualitative Verstehen of departures from that default;

\footnotetext{
${ }^{1}$ Unfortunately there is no recent overview of these controversies placing them all into a single framework or perspective. Each of the many sub-controversies is generally discussed in isolation. Useful surveys of these discussions can be found in W.J. Mommsen and J. Osterhammel, eds., Max Weber and his Contemporaries (London: Unwin Hyman 1987), especially the contributions by Hennis, Schön, Krüger, and Whimster. See also W. Lepenies, Between Literature and Science: The Rise of Sociology (Cambridge: Cambridge University Press 1988) and S. Turner and R. Factor, Max Weber and the Dispute over Reason and Value (London: Routledge 1984), as well as their Max Weber: The Lawyer as Social Thinker (London: Routledge 1994). A more international perspective is given by S. Turner, The Search for a Methodology of Social Science: Durkheim, Weber, and the Nineteenth-Century Problem of Cause, Probability, and Action (Dordrecht: Reidel 1986). The most comprehensive treatment is probably still the unjustly neglected Part II ("Der Methodenstreit in den Sozialwissenschaften”) of Felix Kaufmann’s Methodenlehre der Sozialwissenschaften (Vienna: Springer 1936), translated into English as Methodology of the Social Sciences (Oxford: Oxford University Press 1944).

${ }^{2}$ R. Swedberg, Max Weber and the Idea of an Economic Sociology (Princeton NJ: Princeton University Press 1998), esp. Chapter 6.

${ }^{3}$ F. Ringer, Max Weber's Methodology: The Unification of the Cultural and Social Sciences (Cambridge, MA: Harvard University Press 1997); S. Eliaeson, Max Weber's Methodologies (Cambridge: Polity 2002).
} 
he also regarded the default processes themselves as not fully determined - in a Marxian or any other way - but rather as amenable, at least partly, to qualitative understanding of their wellsprings. This part of his view was the inheritance from German historicism.

Weber's synthesis has never commanded universal assent, but directly or indirectly it has informed a broad cross-section of research in economic and social history, emanating from a number of different historical schools in Europe and America over the past century. ${ }^{4}$ Most economic and social historians have adhered, explicitly or not, to some version of Weber's project of fusing the subjective and objective points of view in the study of past societies. This was true also, to varying degrees, of the renewed attempts to make history more rigorous and quantitative in the $1950 \mathrm{~s}$ and $1960 \mathrm{~s}$. These attempts took three main forms: first, the Annales school in France, then the Cambridge Group in England, and finally the "cliometric" economic historians in America. ${ }^{5}$ An enormous amount of important research has emanated from all three. Unfortunately, though, the methodological framework informing their work was never spelled out very clearly. This lack of methodological self-consciousness has turned out to be a serious weakness. Quantitatively-oriented historians have had little to say in response to the recent widespread rejection of quantitative methods by historians.

Unfortunately, Weber's own methodological writings are somewhat obscure and their exact interpretation is controversial. Rather than entering those interpretative debates, or attempting a more general statement of social-science methodology, we propose to focus on significant work actually done by real historians. In this paper we make explicit, and present arguments for, a research programme that has long been implicit in the practice of some social and economic historians, especially in the Annales and Cambridge traditions. We suggest that in this practice the very distinction between qualitative and quantitative evidence, on which so much seems to depend in more abstract discussions, is questionable. Many of the greatest advances in understanding past societies over the past fifty years, we suggest, have resulted from the deliberate use of qualitative evidence for quantitative purposes. The same body of evidence, used both qualitatively and quantitatively in dialectical interchange, can yield far richer

\footnotetext{
${ }^{4}$ S.L. Engerman, "Max Weber as Economist and Economic Historian”, in S. Turner, ed., The Cambridge Companion to Max Weber (Cambridge: Cambridge University Press 2000), pp. 256-271. A. Spiethoff, “Anschauliche und Reine Volkswirtschaftliche Theorie und ihr Verhältnis zueinander”, in E. Salin, ed. Synopsis: Festgabe für Alfred Weber (Heidelberg 1948), pp. 567-664, gives more details on Weber's influence in the German and Central European traditions. ${ }^{5}$ The conscious or unconscious use of Weber, especially in the recent emphasis within cliometrics on the development and effects of different institutional frameworks, is emphasized by Engerman "Max Weber". The Annales school tended to a more Durkheimian approach, though this began to change in the 1960s. Among the three recent schools of quantitative historians, as we will argue below, the practice of the Cambridge Group best exemplifies the Weberian aspiration to fuse qualitative and quantitative methods.
} 
insights than either in isolation. By making this practice explicit, we hope to lay a basis for moving forward from Weber, ${ }^{6}$ rather than continuing to revisit the endless controversies he provisionally resolved.

In the following section, we review the contributions of the three more recent schools to the interrelation of quantitative and qualitative evidence, and discuss how their approaches differed. In Section 2, we argue for the informativeness and value of quantitative uses of qualitative evidence, especially for the approach practised (though rarely preached) by the Cambridge Group. In Section 3, we suggest a dialectical model, based on this "micro-exemplary" approach, as we will call it, for the interplay of qualitative and quantitative evidence in economic and social history. In Section 4, we illustrate this approach with specific studies which have employed such a dialectic between qualitative and quantitative evidence. In the final section, we appraise the future prospects of this Weberian, dialectical, "micro-exemplary" method. To prevent misunderstandings, we emphasize right at the outset that this method, even if specified in far greater detail than we have attempted here, could never become a formula or an algorithm, mechanically applicable to any given problem, or that it could replace historical judgement. In history, unlike more theoretical areas of study, we do not think there will ever be a way to avoid getting one's hands dirty.

\section{Turning Qualitative into Quantitative Evidence: The Beginnings}

Nineteenth-century German historians in the tradition of Ranke created a new standard of evidence for historical assertions about diplomatic and political history. Since their day, it has been unacceptable to make such assertions without indicating what evidence there is for them, and where that evidence is to be found. In other kinds of history, uncritically accepted lore about the past continued to be transmitted and believed even by educated people. Common to most nineteenth-century social and economic history, including that of Marx, Roscher, Sombart, and even Weber himself (in his own historical practice), is, for instance, the assumption that concepts such as "state", "property", "church", "family", "household”, "capitalism", "law", "community", and so on have definite, stable, fixed

\footnotetext{
${ }^{6}$ We make no effort here to argue in detail that our proposal is of just the kind Weber would have endorsed. We regard it as being generally in Weber's spirit, but are more interested in the utility of the proposal itself, as a solution to current problems, than in establishing and documenting its Weberian credentials. In any case, the interpretative obstacles to establishing Weber's exact position on each issue involved are so formidable that any attempt to short-circuit them by a summary discussion would seem disingenuous. These controversies are probably responsible, in fact, for the neglect of explicitly Weberian formulations of method among the leaders of the Annales and Cambridge schools.
} 
meanings in isolation from the actual functioning of these institutions in particular contexts. ${ }^{7}$ Only with the second generation of the Annales school and with the Cambridge Group did the standard of evidence previously required for diplomatic and political history begin also to be applied to social and economic history. The lore about pre-capitalist families, households, and communities was subjected to detailed critical study in particular local situations. In bringing local records to bear on general questions, these historians undertook a significant methodological innovation. They began to use qualitative evidence quantitatively. Most famously, they compiled lists or series of particular recorded events (demographic events, to begin with - births, marriages, and deaths) over comparable periods to obtain quantitative estimates of population, age at marriage, life expectancy, family size, community response to mortality crises, and many other parameters.

The initial results quickly made evident that the societies under study, in France and England, were in many respects quite different from those portrayed in the received lore. But new questions immediately sprang up on all sides. How characteristic of the larger society were the regions or villages first studied? Were there regional differences? Was there a single pattern of development over time, or different ones in different places? More local studies were needed, so that patterns could begin to emerge, the results of different studies could be compared, and eventually a composite picture of larger regions could be built up. This was slow, difficult, laborious work, even after computers had been harnessed to assist in family reconstitutions and other mechanical tasks. What made it especially unglamorous was the absence, at least initially, of any connection between the stark, impersonal facts of demography, landownership, or agricultural productivity and the personal experience of those facts by human beings. The surprising new findings were recalcitrant to easy assimilation by existing political, religious, and literary narratives, and there was no alternative "big picture", no sense of how the surprising new facts

\footnotetext{
${ }^{7}$ Weber, to be fair, at least realized there was a problem here, and in his methodological works (e.g. "Über einige Kategorien der verstehenden Soziologie”, in the collection Gesammelte Aufsätze zur Wissenschaftslehre, 3rd edition (Stuttgart: Mohr/Siebeck 1968), esp. pp. 444-452), proposed that such basic terms at least be defined precisely, as a stable backdrop of "ideal types" to the particular object of study. In the absence of empirical underpinning for their meanings, this at least made it possible to keep track of assumptions. In that sense, the developments described in this section represent an advance over Weber, though in a very Weberian spirit; they suggest a way of giving empirical meanings to basic social concepts, and such "empirical ideal types" can successively replace the purely definitional "ideal types" Weber saw no way around. They can be regarded as rational reconstructions or explications of those makeshift definitions. The new methods described in this paper make it possible to reduce the non-empirical background of arbitrarily defined "ideal types" to a minimum. Like all Weber's concepts, that of "ideal type" has been interpreted in widely divergent ways; our interpretation here is most consistent with that of Kaufmann, Methodenlehre, pp. 224ff. and of P. Raynaud, Max Weber et les dilemmes de la raison moderne (Paris: Presses Universitaires de France 1987), pp. 49-60, as well as those of Schweder, Engerman, and Spiethoff.
} 
could be reconciled with the established political, religious, and literary narratives that had always been the stuff of history.

This lack of connection was addressed in interestingly divergent ways over the following years. In France, a Durkheimian structuralism (augmented by a Vidalian geographical and also a climatological dimension) predominated, ${ }^{8}$ exemplified by Braudel's broad canvasses, where the rigid structures and cyclic conjonctures tightly constrained, or perhaps even fully determined, the superstructure of évenements (the "foam on the surface"). Ideologies and institutions, notoriously, had little place in this scheme, even in the first generation of Annales regional studies, e.g. Goubert's study of the Beauvaisis. Le Roy Ladurie's study of Languedoc also followed this pattern, but less rigidly; ideologies and local politics made an appearance, as constrained but not fully determined by the structures and conjonctures. However, there was little attempt to integrate these ideological and institutional processes on the micro-level, beyond a series of vignettes and examples designed to illustrate the personal impact of price fluctuations or land consolidation, and a loose, highly speculative narrative suggesting how popular ideologies might have been constrained or influenced by price movements and agrarian conditions. ${ }^{9}$ Indeed, religious ideologies and the spread of the French language were generally treated as impersonal processes or "ideological structures" ${ }^{10}$ that spread in the manner of epidemics. Individual human experience was no longer absent from the picture, but individuals, families, and communities were merely objects, not subjects, of history.

A more rigorous attempt within the Annales tradition to relate ideology and hard facts directly was made somewhat later by Michel Vovelle, who thought of a new way to use qualitative documents quantitatively. Looking at the total and proportionate value of bequests to various categories of recipient in thousands of eighteenth-century Provençal wills, he was able to measure the decline in

\footnotetext{
${ }^{8}$ Some would rate the influence of Vidal de la Blache on the Annales school even above that of Durkheim, e.g. R.M. Smith, "Geographers, Annaliste Historians, and the Roots and Divergent Pathways of English and French Historical Demography", unpublished paper (2003). The influence of Vidal is undeniable, but S. W. Friedman, Marc Bloch, Sociology, and Geography: Encountering Changing Disciplines (Cambridge: Cambridge University Press 1996) argues that Bloch followed neither path, but rather effected a synthesis between them. A similar argument for Febvre is given by B. Müller, Lucien Febvre, lecteur et critique (Paris: Albin Michel 2003), pp. 239-265. Braudel's device of (largely geographical) structures overlaid by (social and economic) conjonctures can be seen in a similar light. In any case, both Vidal and Durkheim are variants of a scientific structuralism in the Comtean tradition, while Weber's synthesis of structural and subjective elements relies heavily on his neo-Kantian background; see below, note 39 .

${ }^{9}$ See the criticisms of Le Roy Ladurie's speculations about witchcraft, for instance, in S. James, The Content of Social Explanation (Cambridge: Cambridge University Press 1984), pp. 166-171 and S. Clark, Thinking with Demons: The Idea of Witchcraft in Early Modern Europe (Oxford: Oxford University Press 1997), pp. 25-26.

${ }^{10}$ E. Le Roy Ladurie, The Peasants of the Languedoc (Champagne, IL: University of Illinois Press 1974), pp. 149ff.
} 
commitment to the church ("dechristianization") more directly than in the rather impressionistic picture Le Roy Ladurie had painted, by the decline in the relative and absolute amounts of money people left to religious institutions over this period. There was still no direct confrontation or interrelation here between ideological dimension of "dechristianization" and the "structures" of hard fact - demography, biology, geography - or of economic “conjunctures”, but it was a major advance to obtain a more direct measurement of an "ideological" factor, and to relate this measurement to qualitative, literary evidence allowing insight into personal experience. ${ }^{11}$

Though Vovelle's study brought the Annales school closer to Weber's programme of integrating subjective experience with objective facts than the Vidalian-Durckheimian structuralism of previous Annales regional studies, it was still much further removed from it than the direction already taken, at that point, by the Cambridge Group. Here we find, right from the outset, in Peter Laslett's 1963 study of household structure in Clayworth and Cogenhoe, that demographic facts are put in a qualitative, local context of particular villages. This paper anticipated many of the subsequent preoccupations of the Cambridge Group, which was just coming into existence. It contains extended discussions of household size and headship, migration and servanthood, the social and income inequalities among villagers, their occupations, and also of other local institutions. No new methods were involved. Laslett would soon be inspired by the method of family reconstitution from parish registers developed by the French demographer Louis Henry, whereupon he and Tony Wrigley would put the Cambridge Group to work on producing such reconstitutions on a large scale. But even before these highly labourintensive methods were considered, Laslett's approach to the study of households was quite different from Henry's or that of the Annales school. Instead of merely using household data for demographic analyses, or of distilling quantitative results from the Rector's book kept from 1676 to 1701 by William Sampson, the rector of Clayworth, such sources were used to paint a detailed picture of the functioning of a local society against the quantitative backdrop obtained from them. It was only a beginning, and it would be a decade before full-scale village or community studies were undertaken along these lines. But it was already evident that the goal and approach were quite different from those of Goubert or Le Roy Ladurie. The goal was avowedly not an "histoire totale" ${ }^{12}$ but the reconstruction of a historical community, in the way that an anthropologist would reconstruct the internal functioning and social relations of a village she had lived in and observed first hand. The demographic and economic facts were

\footnotetext{
${ }^{11}$ M. Vovelle, Piété baroque et déchristianisation en Provence au XVIIIe siècle: les attitudes devant la mort d'après les clauses des testaments (Paris: Plon 1973).

${ }^{12}$ See below, pp. 24-26 and p. 39.
} 
not simply recorded and aggregated and taken as evidence for larger-scale "stuctures" or "processes" which were then explained independently. On the contrary, they were just a starting point, a background against which the complex social and institutional life of the village could then be reconstructed - not in its entirety, but enough so that the particular question or problem of interest could be seen in three dimensions, within the context of an interlocking set of practices, norms, and institutions.

Oddly, this highly original approach to the reconstruction of historical communities was not articulated as an explicit programme of the Cambridge Group in its founding documents. ${ }^{13}$ It became an established and understood practice within the Group, but was consciously stated as a programme only in the later 1970s by Alan Macfarlane and his village study project - acknowledging the inspiration of Peter Laslett and the Cambridge Group. ${ }^{14}$ The question of how and why Laslett and some other members of the Cambridge Group adopted this approach, especially in the absence of an explicit programme, remains something of a mystery. ${ }^{15}$ Given Laslett's staunch commitment to the use of quantitative evidence wherever possible,${ }^{16}$ and his partnership with Wrigley (whose more geographical perspective put him closer to the Vidalian-Durkheimian structuralism of the Annales school), the anthropological and community-oriented component is an original and somewhat unexpected dimension in the Cambridge Group's approach. It may have come from any number of sources. The only model among contemporary historians that was even within range was the work of W.G. Hoskins, though it made no use of demographic or household sources. ${ }^{17}$ Anthropologists are another possible

\footnotetext{
${ }^{13}$ Not in Laslett's popular book The World We Have Lost (London: Methuen 1965) nor even in his more specifically methodological essay "Social Structure from Listings of Inhabitants", in E.A. Wrigley, ed. An Introduction to English Historical Demography from the Sixteenth to the Nineteenth Century (London: Weidenfeld \& Nicolson 1966), pp. 160208. The first general statement by a member of the Group, as far as we can tell, was E.A. Wrigley The Local and the General in Population History (University of Exeter 1985), published as a typewritten pamphlet. We have not explored the Group's archives to see whether there might have been unpublished statements of method, e.g. in early grant proposals. ${ }^{14}$ A. Macfarlane et al, Reconstructing Historical Communities (Cambridge: Cambridge University Press 1977), pp. xi-xii.

${ }^{15}$ Village studies of other kinds had, of course, already been undertaken; the claim here extends only to the specific kind of village study to be called "micro-exemplary" in Section 3 below. Apart from W.G. Hoskins (see note 17 below), there was the "Toronto School" of medieval historians, who produced village studies (though without the quantitative demographic backdrop employed by Laslett) as far back as 1964; see R.M. Smith, “"Modernization” and the corporate medieval village community in England: scome sceptical reflections”, in A.R.H. Baker and D. Gregory, eds., Explorations in Historical Geography (Cambridge: Cambridge University Press 1984), pp. 140-179, esp. pp. 155-157. Smith himself (the author of the first full-scale 'micro-exemplary' study; see below, Section 4) was apparently influenced by the presence of J.A. Raftis at Peterhouse in 1968-9, but there is no evidence that Laslett was influenced by the Toronto historians.

${ }^{16}$ One of the more uncompromising, but by no means atypical, statements to this effect is the introduction to Family Life and Illicit Love in Earlier Generations: Essays in Historical Sociology (Cambridge 1977), entitled "Introduction: The Necessity of a Historical Sociology".

${ }^{17}$ W.G. Hoskins, The Midland Peasant: The Economic and Social History of a Leicestershire Village (London: Macmillan 1957). In its effort to use qualitative and quantitative evidence in a mutually supportive (though hardly systematic) way, and to use a single village as a 'microcosm' of the larger society (see note 38 below), this study of the village Wigston Magna
} 
influence; Meyer Fortes, Jack Goody, and Edmund Leach are acknowledged in the introduction to The World We Have Lost. There may even have been an indirect Weberian influence via Laslett's sociological friends; in the same introduction he writes, "I owe a great deal to Edward Shils, my caustic mentor now for nearly twenty years". 18

However it came about, it seems clear that the Cambridge Group emphasis on reconstructing historical village communities, especially its close integration of rigorous quantitative study with a qualitative understanding of the institutional and social framework within which villagers interacted (as a kind of subjective, participative, quasi-anthropological Verstehen of their motives, against the backdrop of their measurable, objective - physical, biological, institutional - constraints), comes closer than almost any other research programme after 1945 to being a full realization of Weber's methodological ideas. And at the core of this approach is a particular strategy for using qualitative evidence quantitatively. The micro-level qualitative evidence is not simply turned into quantitative evidence which is then discussed or analyzed at the macro-level; it is, rather, held responsible to influences or interactions that can be observed at the micro-level itself. This goes hand in hand with focus on the micro-level as the level where the interface, the point of contact, between larger external trends (state formation, market growth) and individual humans is directly observable. There was thus a focus on smaller units than traditional economic history (or the Annales school, or the cliometricians) had usually studied: household, manor, community, local institutions. The quantitative estimates that arose from qualitative evidence were confronted with that qualitative evidence as qualitative, as well as with other available qualitative data, so that the qualitative and quantitative data illuminated each other. In the next section, we argue that this research strategy leads to a deeper and better understanding of past societies than the use of either quantitative or qualitative evidence in isolation.

deserves to be called at least a forerunner, if not the first actual example, of the 'micro-exemplary' method. The main element still missing, apart from the household and demographic dimension, was any use of record linkage (see below, Section 3). Hoskins personally was very supportive of the Cambridge Group’s work in its planning phases and early years, and attended a crucial planning meeting in July 1964 along with Wrigley, Laslett, Goubert, and Henry.

${ }^{18}$ Laslett also had frequent contact with Anthony Giddens. Another possible source is Karl Mannheim, who was sought out in London by Laslett in 1939 when he was a rebellious research student at Cambridge, as he recounts in the memoir "Karl Mannheim in 1939: A Student's Recollection”, Revue européenne des sciences sociales et Cahiers Vilfredo Pareto 17 (1980), pp. 223-226, which concludes (p. 226), "I am still surprised when I glance again at Mannheim’s works (for I can never bring myself to read them through) at what I reproduce as mine, believing it to be so, which yet in fact was his." The same may of course have been true, for Laslett, of Weber's works. 


\section{The Indispensability of a Quantitative Component in Historical Knowledge}

To many social and economic historians, the value of a quantitative component in history is so obvious that they have never tried to spell it out. This has left them somewhat baffled and speechless in the face of the recent widespread rejection of quantitative approaches among historians. In this section, we try to make explicit why quantitative evidence, as used in at least some of the approaches discussed above, not only enriches and deepens, but is actually indispensable for, the understanding of qualitative evidence. It is impossible to understand a qualitative document from the past, we will argue, without a knowledge of the basic categories or parameters of the society (such as "household" or "property" or "law") in which it was written or uttered. And these basic parameters have no inherent, cross-cultural or universal meanings; their meanings have to be found out. Nor can the role and significance of these basic parameters in a particular society be established by looking at that society in isolation; only by comparing it with other relevant (e.g. nearby, or in some other way similar) communities can the role of such parameters in a particular community be understood. And such a comparison, we argue, is inherently (if in practice not always explicitly) statistical: to undertake such a comparison, we must determine the distribution of some variable of interest over a range of possible values.

In itself this claim is perhaps not very controversial; what inflames passions is the degree to which such statistical or quantitative comparisons should set the tone within the whole enterprise. Nearly all historians accept that the medium of historical discourse is and should be ordinary language, rather than a system of precise and unambiguous concepts such as those employed in chemistry or economics. On the other hand, nearly all historians also accept that, at least around the edges, the vagueness and imprecision of ordinary language must be remediated by auxiliary concepts from other, more precise systems of thought, in which a higher degree of uniformity has been imposed on usage than ordinary language affords. What has been controversial among historians since the nineteenth century has been the degree to which these "other systems of thought" with their more precise concepts can or should be allowed to encroach on traditions of historical writing and thought previously untroubled by them.

A wide range of alternatives has been proposed, but they can be seen as falling into two broad types of approach, corresponding to two major priorities in any historical inquiry. On the one hand, we want to understand a society in its own terms. Like the anthropologist or participant observer, we want to understand the significance of the past society's events and institutions to the people who lived in it. Second, we want to understand the underlying processes in the society, the forces and constraints that 
were causing the stream of interactions and events, the institutional evolution we observe in it. Like the economist or biologist, we want to make sense of the past society's events and institutions in our terms. The first priority might be called a first-person perspective, the second priority a third-person perspective. In terms of history as a discipline, the first priority might be called "historicist", the second "materialist" (or "Marxist"). It was Weber's great achievement to have fused these two priorities into a single approach, to have given them both a place within the historical enterprise. ${ }^{19}$

But this did not put a stop to the controversy about how far precise concepts from "other systems of thought" should encroach on ordinary language within the historical enterprise as a whole. Such disputes result almost inevitably from the continuing problem of definition forced on history by its use of ordinary language as the basic medium of thought and exposition - its use of ordinary language, that is, as its basic "meta-language" for discussing the discourse of the society under study (the "object language"). ${ }^{20}$ The proposals for dealing with this problem have fallen into the two patterns just discussed, the historicist and the materialist. The historicist proposal is essentially that we should make our concepts precise by systematically uncovering the conceptual system of the past society we are studying, and make our meta-language immanent to the society being studied (i.e. our meta-language of historical discussion should become the object language; the distinction between them should be obliterated). The materialist approach, in contrast, seeks to impose our own concepts on past societies, even if these concepts would have been quite unrecognizable to the people being studied. (In this approach, once again, the distinction between meta-language and object language disappears; in this case, the object language disappears; the behaviour of the society is analyzed entirely in terms of our imposed meta-language.)

\footnotetext{
${ }^{19}$ Engerman, "Max Weber"; Schweder, Max Weber. The latter also remarks that the ideas about integrating rational choice theory and sociology in James Coleman’s Foundations of Social Theory (Cambridge MA: Harvard University Press 1990) "are considerably closer to what Weber tried to accomplish than much of what goes under the heading of Verstehen in contemporary sociology” (p. 4). See also Turner, Search for a Methodology, Chapter 9, and Turner and Factor, Weber. ${ }^{20}$ The distinction between "object language" and "meta-language" derives from mathematics, where it was first introduced by David Hilbert, and was used to significant effect within logic by Alfred Tarski and Kurt Gödel in the late 1920s. It was applied within philosophy more generally by Rudolf Carnap in his Logische Syntax der Sprache (Vienna: Springer 1934); English translation The Logical Syntax of Language (London: Routledge 1937). This book has generally been taken to mark the "linguistic turn" within analytic philosophy; e.g. see the editor's introduction to Richard Rorty, ed., The Linguistic Turn: Recent Essays in Philosophical Method (Chicago: University of Chicago Press 1967). Note that in most scientific contexts, the objects of study carry on no discourse, so there is no object language in our sense. In philosophical parlance, a 'meta-language' is usually the language in which the language of a scientific theory is studied (e.g. its logical properties). In that philosophical sense, a meta-language of the language in which historians study their object societies would thus be a meta-meta-language with respect to those object languages.
} 
Within the past fifty years, the most striking example of the historicist approach to definition has undoubtedly been the project of a gigantic compendium of Geschichtliche Grundbegriffe (Fundamental Historical Concepts) launched after 1945 by two great post-war figures of the German historical profession, Otto Brunner and Werner Conze, and completed in the 1980s by Reinhart Koselleck and others. ${ }^{21}$ A whole generation of German historians was drawn into this project, and it continued to influence many participants even after they had subsequently taken somewhat different directions. ${ }^{22}$ The premise of this undertaking was spelled out by Otto Brunner in his famous 1943 book Land und Herrschaft (Land andLordship). ${ }^{23}$ Modern historians misunderstand past concepts, Brunner held, and are thus incapable of reading past documents, because society has changed so much that the use of important words has also changed, quite radically. To make past documents comprehensible to us, we must undertake a thorough archaeology of the use of basic social concepts in different periods. This idea, which to our ears has a Wittgensteinian or ethnomethodological ring, was almost certainly influenced more directly by German historicism. ${ }^{24}$ In this sense, the Fundamental Historical Concepts

\footnotetext{
${ }^{21}$ O. Brunner, W. Conze, and R. Koselleck, eds. Geschichtliche Grundbegriffe: Historisches Lexikon zur politisch-sozialen Sprache in Deutschland, 9 vols. (Stuttgart: Klett-Cotta 1972-1997).

${ }^{22}$ The authors of P. Kriedte, H. Medick, and J. Schlumbohm, Industrialisation before Industrialisation: Rural Industry in the Genesis of Capitalism (Cambridge: Cambridge University Press 1981), for instance, continued to endorse Otto Brunner's concept of the "ganzes Haus" (or “whole household”; see O. Brunner, "Das 'ganze Haus' und die alteuropäische “Ökonomik” (1950), reprinted in his Neue Wege der Verfassungs- und Sozialgeschichte, 2nd ed. (Göttingen: Vandenhoek und Ruprecht 1968)), in which "the unity of production, consumption, and . . reproduction, which was the characteristic feature of the peasant household and family, formed the basis of the economic and socio-political order" in pre-industrial Europe" (Kriedte, Medick, and Schlumbohm, p. 38).

${ }^{23}$ O. Brunner, Land und Herrschaft: Grundfragen der territorialen Verfassungsgeschichte Österreichs im Mittelalter, 5 th ed. repr. 1973 (Darmstadt: Wissenschaftliche Buchgesellschaft 1973). Translated into English as Land andLordship : Structures of Governance in Medieval Austria (Philadelphia: University of Pennsylvania Press 1992). The programme was subsequently given greater philosophical and rhetorical sophistication by Reinhardt Koselleck and others; e.g. the essays collected in R. Koselleck, ed., Historische Semantik und Begriffsgeschichte (Stuttgart: Klett-Cotta 1978), esp. Koselleck's own contribution, "Begriffsgeschichte und Sozialgeschichte", pp. 19-36.

${ }^{24}$ Brunner, Land und Herrschaft, esp. pp. 17-41. Brunner's ideas were thought worthy of an extended critique by Fernand Braudel, "Sur une conception de l'histoire sociale" Annales E.S.C. 14 (1959), pp. 308-319, repr. in Écrits sur l'histoire (Paris: Flammarion 1969), pp. 175-191. A defence of Brunner against these and other criticisms is attempted by O.G. Oexle, 'Sozialgeschichte - Begriffsgeschichte - Wissenschaftsgeschichte: Anmerkungen zum Werk Otto Brunners”, Vierteljahrschrift für Sozial- und Wirtschaftsgeschichte 71 (1984), pp. 305-341, who argues that Brunner was not 'historicist' in the above sense, but was well aware of the need to use modern concepts - provided we remain aware of their historical relativity. Oexle fails, though, to deflect Braudel's central objection to Brunner's "two-dimensional” approach to social history. In Braudel's view, history must triangulate on the past from different viewpoints (p. 191) - in our terminology, it must not only retain, but actively construct, a meta-language. Oexle bravely faces the awkward fact that Brunner not only explicitly endorsed National Socialism in Land und Herrschaft but was largely motivated by the programme of Carl Schmitt (ibid., pp. 318-321). It seems odd, then, that further revelations of Brunner's involvement with the Nazis (along with a number of other prominent historians of his generation - such as Conze, his co-editor of Historische Grundbegriffe), should have caused such a stir at the German Historical Association Meeting (Historikertag) in September 1998; see V. Ulrich, "Späte Reue der Zunft” Die Zeit No. 39, 1998 as well as the articles by U. Rauff and M. Köhler, respectively, in Frankfurter Allgemeine Zeitung, No. 121 (28 May), 1997, p. N5 and No. 211 (11 September), 1998, p. 70.
} 
project really just took to an extreme the approach to definition long practiced among historians, especially legal historians in the tradition of Savigny and Maine.

The most striking example of the materialist approach, on the other hand, has over the past half-century been not the Vidalian-Durckheimian geographically- and climatically-oriented historical demography of the Annales, but rather the even more extreme approach of the American cliometricians. Here the method has been that of "positive economics", ${ }^{25}$ where the subjective view of participants in the social processes being studied is not considered. The minimal unit of study in economics has generally been a particular market, ${ }^{26}$ not the behaviour of particular individuals or even of institutions. There is no requirement, in economics, that the participants in markets are even aware of the behaviour being studied, much less that they have an intuitive understanding of the determinants of or constraints on that behaviour. To speak in materialist terms, the economist generally assumes, in practice, that "false consciousness" is widespread - that participants in market processes behave as they do without awareness of the larger forces leading them to behave in these ways. The cliometricians, accordingly, have shown little interest in the specific impact of larger structures or trends on the local level - i.e. in the interaction of institutions or communities with markets at the point of contact. ${ }^{27}$

The approach of the Cambridge Group, on the other hand, approximated a Weberian middle way between these two extremes (between the historicism of Geschichtliche Grundbegriffe and the materialism of cliometrics). Unlike these extremes, it maintained a distinction between the historian's meta-language and an object language, the discourse of the society being studied; it did not absorb either into the other. Its mode of concept formation, therefore, was both immanent and imposed. A good illustration is the well-known Cambridge Group approach to the study of families and households.

\footnotetext{
${ }^{25}$ As perhaps most trenchantly expressed by Milton Friedman, “The Methodology of Positive Economics”, in his Essays in Positive Economics (Chicago: University of Chicago Press 1953), pp. 3-43. A recent statement, more fully worked out and related to philosophical and statistical schools of positivism, and with particular reference to econometrics, is to be found in H. Keuzenkamp, Probability, Econometrics, and Truth: The Methodology of Econometrics (Cambridge: Cambridge University Press 2000).

26 "Market" not in the ordinary-language sense of a particular location in which buying and selling takes place but in the economists' sense of a certain set of relationships among buyers and sellers of a particular good or set of goods.

${ }^{27}$ In recent years, it is true, some economists have become much more interested in institutions, and there is even a movement to use game theory as a device to model interactions at the local level, e.g. R.H. Bates, A. Greif, M. Levi, J.-L. Rosenthal, and B. Weingast, Analytic Narratives (Princeton, NJ: Princeton University Press 1998). This approach is specifically advanced as a way to mimic the dimension of intuitive understanding of local institutions required in the Weberian framework. It strikes us, though, that the very features of game theory that suggest this possibility (its flexibility and lack of unique equilibria) also ultimately limit the progress that can be expected from this replacement; game-theoretic modelling will ultimately still be guided by intuition, so it will not replace intuition but be a kind of parallel language for its expression. In any case, this approach does not engage with object languages any more than any other form of cliometrics.
} 
From its beginnings in Laslett's above-mentioned study of Clayworth and Cogenhoe, this approach has now given rise to a small subdiscipline with its own internal standards and characteristic expertise, its own conferences and journals. ${ }^{28}$ Its method can be characterized, using the above terms, as on the one hand immanent, in the sense that it is bottom-up; it starts from what we know directly (from primary documents - particularly household listings and censuses) about the societies we are studying, and not from a pre-existing external conceptual apparatus. But it also imposes on these primary data an ad hoc classificatory framework (the Laslett-Hammel household classification ${ }^{29}$ ) designed specifically to bring out differences among household forms that are of interest from various theoretical points of view. Much of the expertise developed in this area consists in the iterative solution to a straightforwardly empirical problem: how to make the widely scattered evidence about household forms comparable across different social strata, occupations, communities, regions, societies, or continents. The LaslettHammel classification has been criticized for privileging cross-sectional over longitudinal analysis and using categories specific to England or Europe. ${ }^{30}$ But where longitudinal sources are available they yield findings consistent with those of the (far less scarce) cross-sectional sources. Furthermore, alternative classificatory schemes have proved much more culture-specific, as shown by the fact that Laslett-Hammel continues to be used by the vast majority of household studies, because it both enables systematic comparisons across societies and permits flexible extensions and variations to suit the specificities of particular societies. ${ }^{31}$ In the forty-year process of developing the techniques of household analysis, a great deal of knowledge has accumulated about the kinds of households to be

\footnotetext{
${ }^{28}$ Thus, for instance, the analysis of census-type household listings along the lines laid down by Laslett beginning in 1963 informs a large majority of articles in the Journal of Family History (founded 1975), Continuity and Change (founded 1985), and The History of the Family (founded 1996).

${ }^{29}$ This classification scheme divides households into five main types (solitary, no-family, nuclear family, extended and multiple), each involving a multiplicity of sub-types; each type can also be modified according to the presence of servants and "inmates" (lodgers, boarders, etc.). For the classic exposition of this classification scheme, see E. A. Hammel and P. Laslett, "Comparing Household Structures over Time and between Cultures", Comparative Studies in Society and History, 16 (1974), 73-109.

${ }^{30}$ For a representative selection of the classic critiques of the Laslett-Hammel scheme, see L. K. Berkner, "The Use and Misuse of Census Data for the Historical Analysis of Family Structure”, Journal of Interdisciplinary History, 4 (1975), pp. 724-30; J. Lee and J. Gjerde, “Comparative Household Morphology of Stem, Joint, and Nuclear Household Systems: Norway, China, and the United States", Continuity and Change, 1 (1986), 89-112; T.K. Hareven, "The History of the Family and the Complexity of Historical Change”, American Historical Review, 96 (1991), pp. 95-124; D. I. Kertzer, "Living with Kin”, in D. I. Kertzer and M. Barbagli (eds.), The History of the European Family, 2 vols (New Haven: Yale University Press, 2002), vol. II, pp. 40-47.

${ }^{31}$ For particularly thoughtful and constructive engagements with the detailed criticisms of the Laslett-Hammel classification scheme in combination with practical demonstrations of the robustness with which it can be extended to deal with different family systems and its indispensibility in comparative analysis, see R. Wall, "The Transformation of the European Family across the Centuries”, in R. Wall, T. K. Hareven, and J. Ehmer (eds.), Family History Revisited: Comparative Perspectives (Newark: University of Delaware Press, 2001), pp. 217-241, here esp. pp. 219-221; T. W. Guinnane, The Vanishing Irish: Households, Migration, and the Rural Economy in Ireland, 1850-1914 (Princeton, NJ: Princeton University Press, 1997), esp. pp. 139-146; and T. K. Dennison, "Serfdom and Household Structure in Central Russia: Voshchazhnikovo 18161858”, Continuity and Change 18 (2003), pp. 395-429, esp. section III (“Methodological Issues”), pp. 398-404.
} 
expected in various kinds of economic and social environments, about the demographic causes and consequences of household forms, and so on. But these higher-level "theoretical" considerations did not drive the process of empirical concept formation. ${ }^{32}$ The basic empirical concepts of this literature were developed in response to the data from past societies, and remained close to those data. But rather than using the concepts employed by those societies, this Cambridge approach imposed an ad-hoc set of intermediate (though empirically-oriented) concepts to enable modern researchers to consider the behaviour of the past society from their own points of view (whether these be sociological, economic, political, or anthropological).

It is important to be clear that this approach is not a compromise, a half-way station, between historicism and materialism, between immanence and objectivity. It is a genuine synthesis, and thus something fundamentally different in conception from either. It is, in a sense we will make more precise in the following section, a dialectical approach that tries to get equally beyond a slavish immersion in the historical categories of the societies under investigation (expressed in the object language) and beyond a domineering imposition of our own theoretical (meta-language) categories on empirical evidence to which they are in the first instance incommensurable - and to arrive at a progressive interplay between the voices of the sources themselves and our own analytical categories.

We emphasize once again that the approach we are trying to make explicit here was never fully spelled out. It was practised without being preached, at least by its founders. It was taken as given, as a set of unspoken assumptions, by many who worked within the Cambridge Group and its very wide diaspora. Keith Wrightson, for instance, in a review of David Hey's study of Myddle, ${ }^{33}$ criticizes the reliance on a single qualitative source (the history of Myddle written by one of its yeomen, Richard Gough, in the late seventeenth century) without testing its perceptions using other documents. The result, says Wrightson, is that Hey "is rarely able to give more than an impressionistic discussion of issues which demand rigorous examination”. Wrightson is particularly sceptical of Hey’s reliance on Gough regarding the "homogeneity of attitudes, interests, and behaviour among all save the 'bad families" of the parish", and the resulting picture of social and doctrinal conformity during this period. "These

\footnotetext{
${ }^{32}$ As they appear to have done, for instance, in the classification schemes devised by the Toronto School; Smith, "Corporate Village Community", pp. 156-157 and p. 174 suggests that some at least of the results achieved by these studies were "solely an artefact of [the] method".

${ }^{33}$ Wrightson, "Villages", pp. 635-6, reviewing D. Hey, An English Rural Community: Myddle under the Tudors and Stuarts (Leicester 1974).
} 
arguments," Wrightson says, giving eloquent voice to the Cambridge approach we have been describing,

... depend for support upon Gough or upon silence, upon the comments of a sternly pious yeoman or upon the silence resulting from a dearth of source materials against which to test the accuracy and completeness of his testimony or the typicality of his attitudes. The registers of the parish offer little hope of accurately assessing the incidence of illegitimacy or bridal pregnancy. The area lacks the full series of ecclesiastical court or Quarter Sessions records which might, and in other counties do, contain valuable evidence of behaviour, sources of conflict, attitudes and opinions in village society. Where such evidence is forthcoming, a disciplined attempt can be made to establish the nature of the norms governing village life and the extent to which men deviated from them. The prescriptions of contemporary moralists and the opinion of men like Gough can be tested against independent evidence. ${ }^{34}$

This is both a more open-minded and a more sceptical approach to sources than the historicist one. It is more open-minded in that it does not impute a single homogeneous use of language to all the actors in a past society (as the Brunner and Koselleck approach implicitly does), but rather takes account of a polyphony of often conflicting voices. And it is more sceptical in that it does not assume that the language used in a society necessarily corresponds to its norms, or its norms to the actions of individuals. These are matters to be investigated empirically, not to be assumed in advance. On the other hand, neither does this approach turn its back on the immanent view altogether, as the materialist approach does; it does not seek to impose some completely external, incommensurable theory on the actions of villagers but takes its starting point, rather, in their sayings and doings. ${ }^{35}$

At the heart of this approach is a characteristic way of turning qualitative into quantitative evidence, in which this transformation is not a one-way street, and in which quantitative and qualitative evidence are progressively and iteratively confronted with each other in the context of a particular focus of interaction, a particular local community. Quantitative evidence from qualitative sources is used to resolve doubts about reliability and inconsistencies among qualitative sources. It enables us to know which norms actually influenced behaviour and which did not, which laws were enforced and which

\footnotetext{
${ }^{34}$ Wrightson, "Villages", p. 636.

${ }^{35}$ We must also emphasize, once again, that it is somewhat mysterious where this rarely articulated approach comes from. Wrightson's remark offers a clue, however. Laslett (his doctoral supervisor) began as a student of political thought, and as one who, long before this became widespread, attempted to understand what past political thinkers were saying in the context of the society they were addressing. His interest in the early modern English family and household seems to have been aroused, specifically, by the effort to understand the status of "patriarchy" in writings of Locke and Filmer. Given that the French had shown it was possible to reconstruct past families from parish registers, it seems Laslett was inspired precisely by the idea that "the prescriptions of contemporary moralists and the opinion of men like Gough" - or like Locke and Filmer - "can be tested against independent evidence".
} 
were not, and how well the rhetoric of local clergy matched the realities they were confronted with in their parishes. When we find it claimed that socialization in household and church were effective in transmitting "traditional" values, and that sexual misdemeanors were "negligible", for instance, we want to be sure we have parish registers to enable us, as Wrightson suggests, to assess the incidence of illegitimacy or bridal pregnancy. ${ }^{36}$ If we were to find a high ratio of illegitimacy this would not of course make us ignore our qualitative source, but we would understand it quite differently from Hey's uncritical acceptance at face value. In fact, we only really understand it - at all - by virtue of knowledge independent of such a single qualitative source. It is only by virtue of such independent knowledge that we know "how to take" what qualitative documents tell us. In the absence of such independent knowledge, we have only linguistic artifacts, without any idea of the practice in which any linguistic usage is rooted. ${ }^{37}$

But an illegitimacy ratio is only a beginning; it is not enough by itself. Without a standard of comparison we have no idea whether a ratio from a particular village is "high" or "low". Only the quantitative comparison with ratios of other parishes, in England and Europe, across time and space, and with trends across time in these different places and epochs, enable us to assess whether the particular ratio in question is high or low. We can only gauge the significance of any particular local finding against a background of relevant comparisons. It is in this sense, then, that we only understand even qualitative sources, in the end, by reference to a background system of quantitatively defined terms.

\section{The Progressive Interplay between Qualitative and Quantitative Evidence}

One weakness of past formulations of historical method, including even Weber's, is that the qualitative and quantitative components of historical knowledge are regarded as static. The two categories in themselves are regarded as stable and well-defined. But since the first Annales efforts to use qualitative

\footnotetext{
${ }^{36}$ Wrightson, "Villages", p. 636.

${ }^{37}$ As Wittgenstein famously and comprehensively explained in Philosophical Investigations, the meanings of words in an ordinary language derive from their use in the practical life of the society in which the language is embedded. Meanings of words and sentences, in this conception, are not "in the head", they are not private and subjective, but public artefacts whose objectivity can be established by reference to their range of possible uses. Wittgenstein argues at length against the possibility of a "private language", i.e. the possibility of establishing meanings of words without a surrounding context of practices in which they are embedded and to which they refer. Those who would use qualitative documents, such as Gough's account (or other literary sources), as their sole informants about a past society - without reference to other documents that give us independent access to the society in which the language of those documents is rooted - are in effect, in Wittgenstein's terms, attempting to study that object language as a "private language". Any justification of such a procedure would, at least, have to take on the formidable battery of obstacles adduced in Philosophical Investigations.
} 
evidence quantitatively, this static view is no longer appropriate. We must, instead, focus on the progressive and dynamic interaction between qualitative and quantitative evidence: on the transformation of qualitative evidence into quantitative, and on the dialectic by which quantitative and qualitative evidence are brought to bear on each other. The following outline is a first sketch of how such a process might be conceived. It is a variant on the larger conception developed by Weber and carried on by many others in the past century, and is inspired by the historical work described above. Given its intellectual location within the larger framework of Weber's conception of social-scientific method, it might be appropriate to refer to this approach as the "exemplary (or ideal-type) approach to micro-history". We will call it the "micro-exemplary" approach (or method) for short. ${ }^{38}$

The starting point of this approach is straighforwardly historicist. Immersion in the documents of a past society gives the historian a first-hand acquaintance with it that resembles the acquaintance gained by an anthropologist who lives in a society as a participant observer. The historian develops a total view of the interactions among participants in the institutions or populations of interest, from observing a sample and extrapolating an imaginative picture from this sample. There can still be surprises, of course; at any particular point in the investigation, the total view is always to some degree tentative. But as the sample grows larger, acquaintance becomes closer and more confidant. This, of course, is the classic process of hermeneutic Verstehen, intuitive understanding, so highly prized and emphasized by Droysen and the German historicists. One becomes so well acquainted with, say, the political culture of the papacy at a certain period that one is able to predict quite well how this entity will react in given circumstances. The institutional structure of papal policy-making becomes clear, one understands how the system responds to internal upheavals and external shocks. One understands a totality in which the strategies, opportunities, and risks of particular participants become graspable. ${ }^{39}$ It seems impossible

\footnotetext{
${ }^{38}$ It could also be called the "microcosmic approach", after an aperçu of M.M. Postan, quoted by Wrigley (The Local and the General, p. 1), distinguishing between the legitimate "microcosmic" study of medieval village society, which discerns the general in the local, and the merely "microscopic" preoccupation of the antiquarian. Wrigley uses this reference to Postan to motivate his own refutation of the characterization of local history as "the uninspired in pursuit of the unimportant".

${ }^{39}$ The classic formulation of this historicist understanding of social-scientific epistemology is Gustav Droysen's Historik, which drew on the earlier traditions of hermeneutics, romantic Volkskunde, and local antiquarianism described in Friedrich Meinecke's Die Entstehung des Historismus (repr. Munich: Oldenbourg 1959). The reformulations of this view in the later nineteenth century, e.g. by Dilthey, emphasized the contrast with natural science more strongly, and were more concerned to claim a radical independence of the "human sciences [Geisteswissenschaften]" from the natural sciences. Wilhelm Windelband, in his inaugural lecture at Straßburg in 1894, "Geschichte und Naturwissenschaft", repr. in Präludien: Aufsätze und Reden zur Philosophie und ihrer Geschichte, 6th edition (Tübingen: Mohr 1919), pp. 137-160 framed this distinction as that between maximally general, law-governed or "nomothetic" sciences and the "ideographic" sciences that study particular situations or events holistically in their contexts. Windelband's student Heinrich Rickert systematized and radicalized this view in his magnum opus Die Grenzen der naturwissenschaftlichen Begriffsbildung (1896-1902); Rickert's
} 
to formulate this intuitive "feel" for such an institutional and cultural configuration in other than qualitative terms, by illustrating it narratively, or simply by qualitative, literary description in ordinary language. ${ }^{40}$

This same sort of qualitative immersion in the object language is the starting point, the indispensable precondition, for the mico-exemplary method as well. But what distinguishes all the newer quantitative approaches - not just the Cambridge Group but also the Annales school and cliometrics - from historicism is their shared programme of testing the total, qualitative, hermeneutic view extrapolated from a sample of documents against a background of quantitative concepts in just the way that one could, if documents were available, test the pronouncements of people like Richard Gough about sexual conformity against illegitimacy and bridal pregnancy ratios (and these, in turn, against a broad national and European picture of local and temporal variation among such ratios).

It is also recognized to varying degrees among quantitative historians - though rarely if ever spelled out - that to know what questions to ask, and to make sure these questions are relevant, the strict dichotomy between qualitative, hermeneutic understanding and quantitative, explicit theory (a dichotomy on which both the devotees of regression models and the devotees of "thick description" are prone to insist) must be bridged. There is a continuum between the barest intuitive hunch or inkling at one end and the fully specified regression model at the other end. In history, we cannot afford to insist on all or nothing; we must learn to negotiate the intermediate ranges, and find a way of talking about them. ${ }^{41}$ One does, after all, use one's qualitative, hermeneutic understanding of a society as a basis and framework for constructing a meta-language in which to ask quantitative questions, which thus put the hermeneutic understanding of the object language to the test. The hermeneutic understanding is in effect regarded, then, as a kind of incipient proto-theory, a guide (though not yet a fully articulate or explicit one) to the eventual construction of a system of empirical concepts. It is not regarded as a

influence on Weber has long been a matter of controversy; see G. Oakes, Weber and Rickert: Concept Formation in the Cultural Sciences (Cambridge, MA: MIT Press 1988) and P.-U. Merz, Max Weber und Heinrich Rickert: Die erkenntniskritischen Grundlagen der verstehenden Soziologie (Würzburg: Königshausen \& Neumann 1990). An overview of these developments within German philosophy and social thought can be found in Herbert Schnädelbach, Philosophy in Germany 1831-1933 (Cambridge: Cambridge University Press 1984), Chapters 2 and 4. The nearest English-language equivalent to these German developments, though of less direct influence on historians, was Collingwood's related idea of history as the "re-enactment" of past events by the historian; see W.H. Dray, History as Re-enactment: Collingwood's Idea of History (Oxford: Oxford University Press 1995).

${ }^{40}$ Droysen and others had, of course, already suggested that such description, as it is not theoretical or (in later terms) "nomothetic", must employ the indirection, the metaphorical and rhetorical devices, commonly employed in literary art, i.e. that such description is unavoidably "thick” (in Clifford Geertz's more fashionable term) rather than simply literal.

${ }^{41}$ Cf. R. Schofield “Through a Glass Darkly” Social Science History 22 (1998), pp. 117-130, esp. pp. 128-129. 
purely subjective or intuitive identification incapable of further probing or analysis, but as progressively revisable and improvable. ${ }^{42}$

The characteristic moment that further distinguishes the micro-exemplary from other quantitative approaches, though, is that in its view, such quantitative tests of the hermeneutic understanding do not simply supersede that original qualitative understanding. In the micro-exemplary approach the progress from qualitative to quantitative is not a one-way street, as in some versions of the Annales approach or in cliometrics. The qualitative, intuitive, holistic understanding of the society from immersion in its documents is not displaced by its quantitative explication or cross-checking in the meta-language. The adding of a quantitative cross-check is the beginning, rather, of an open-ended dialectical or mutualfeedback process between the original hermeneutic understanding and quantitative data generated to test it. If the quantitative test contradicts the original understanding in some respect, then the understanding is not simply abandoned, or displaced by some more abstract and precise concept not fully definable on the basis of primary evidence alone. The holistic understanding of the society is, rather, improved by this contradiction; it is revised to accommodate the new fact and thus has more empirical content than its predecessor(s). The most obvious kind of revision will require a return to the qualitative sources and a re-immersion in them to arrive at a new hermeneutic understanding that accommodates the results of the quantitative test. This new understanding will then suggest further quantitative tests, and so on.

But sometimes such a contradiction cannot be repaired this way; the immanent vocabulary of the society itself will be insufficient to repair or revise one's original understanding of it. Instead, the conceptual repertoire has to be expanded; the construction of the meta-language has to be taken a step further. But it is characteristic of the micro-exemplary approach that it takes a minimalist approach to this

\footnotetext{
${ }^{42} \mathrm{~A}$ "hermeneutic understanding" is not usually or unequivocally regarded as corrigible in quite this way, though there is a spectrum of opinion about this. One pervasive theme of Gadamer's Wahrheit und Methode (Tübingen: Mohr/Siebeck 1960 ) is that a hermeneutic understanding cannot be made sufficiently explicit to be directly refutable or confirmable by particular facts, like a theory. This somewhat idealist or coherentist view seems to be the most widespread one within the literature on hermeneutics. A different view of the pre-articulate "grasp" of a configuration or situation by the human mind is that of Ernst Cassirer, who portrays it as a distinct form of symbolic expression or understanding, which - in quasievolutionary language - he calls the "mythic" form. In his view it is the fundamental one on which all "higher" symbolic forms (those of ordinary language and scientific theory) build. This view can now be understood in more directly evolutionary terms, e.g. as equivalent to the "mimetic" culture underlying conscious processing in Merlin Donald's theory of the "hybrid mind", Origins of the Modern Mind: Three Stages in the Evolution of Culture and Cognition (Cambridge, MA: Harvard University Press 1991); a similar theory, independently formulated from a different viewpoint, is put forward by M. Tomasello, The Cultural Origins of Human Cognition (Cambridge, MA: Harvard University Press 1999). These theories suggest that certain kinds of "hermeneutic understanding" can, for practical purposes, be made partly explicit and can thus be criticized in the same general way as a theory, though perhaps by somewhat different means.
} 
expansion. Rather than abandon the immanent discourse of the object language completely, the microexemplary method prefers piecemeal substitution of ad-hoc, bottom-up (data-defined), purely empirical concepts (such as the illegitimacy ratio or the Laslett-Hammel household classification scheme) into the immanent discourse we began with. The raw data extracted directly from the sources is compiled or organized into a loose classification system, a meta-source. ${ }^{43}$ These empirical concepts, then, are used in conjunction with source-immanent language to describe informally, in the first instance, how the local data can be made internally consistent (i.e. without reference, at the outset, to larger, more abstract concepts or to the wider society in which the particular community is located). And this bottom-up process of establishing and testing empirical robustness becomes a foundation for any use of the quantitative data generated from these same qualitative data in higher-level, more abstract theories, or in comparative studies with other localities or a wider society.

But in the micro-exemplary approach those higher-level uses do not prescribe the lower-level empirical categories of the meta-source, the first step in the construction of a meta-language. On the contrary, those lower-level categories are purposely made as independent as possible of higher-level theoretical concerns. ${ }^{44}$ They are the most obvious or "natural" concepts, those that "suggest themselves" to the researcher. Obviousness or "naturalness" here not used here in some ultimate or realist sense. It is not assumed by the micro-exemplary method that there might be some "true" or "correct" set of categories to impose on the processes observed in object-language documents. "Natural" is to be understood here, rather, in an entirely pragmatic way, as something like "unproblematic", or "what we can agree on for now" (we historians with differing theoretical and ideological interests or preoccupations), or "what seems to jump out at us from the sources”. Thus parish registers, for instance, lend themselves "naturally", in this sense, to counting - to being turned into quantitative evidence - because they generally come in the form of physical lists; the discreteness of the items in the list (of demographic

\footnotetext{
${ }^{43}$ As it has appropriately been called by H. Medick, Weben und Überleben in Laichingen 1650-1900. Lokalgeschichte als Allgemeine Geschichte (Göttingen: Vandenhoek \& Ruprecht, 1996), p. 28.

${ }^{44}$ Considerable attention was given to just this question of maximizing flexibility in the early stages of the attempt to harness computers to the transformation of qualitative into quantitative evidence, at a time before relational database software was widely available; R. Schofield and R. Davies, “Toward a Flexible Data Input and Record Management System”, Historical Methods 5 (1972), pp. 115-124; M. Thaller “Automation on Parnassus: CLIO, a Databank Oriented System for Historians”, Historical Social Research/Historische Sozialforschung 15 (1980) and “Datenbankorientierte Verfahren bei der maschinenunterstützten Auswertung historischen Quellenmaterials”, in T. Kneser, ed., Datenverarbeitung in den Geisteswissenschaften (Göttingen, 1980). As Alan Macfarlane put it, “. . . these processses may appear to the non-historian to be fairly trivial matters, yet upon the methods of collecting and preparing the data for subsequent analysis will depend the whole success or failure of a project concerned with studying a particular community" (Reconstructing Historical Communities, p. 81).
} 
events) is presented to us in the form of the document itself; the imposition of quantitative concepts (birth rates, illegitimacy rates, etc.) on the raw sources is minimal. ${ }^{45}$

Even just this first step to such very rudimentary empirical concepts can give us a very powerful external (meta-language) perspective on the object-language sources, and greatly enriches our understanding of the past society under study. The accumulated household literature of the past three decades, for instance, provides a much more empirically robust and reliable grasp of the phenomena it studies than any amount of unguided immersion in household listings or literary evidence or censuses or other documents could possibly have afforded. The household literature provides the researcher with a set of standardized empirical categories that can be applied, with minor modifications, to local data from almost any society worldwide, past or present. But these empirical categories are concrete enough that they do not themselves impose a particular abstract, theoretical (anthropological, economic, or sociological) framework. ${ }^{46}$ Though household investigations are often motivated by such theoretical ideas, they are able to agree on a set of relatively neutral empirical categories which thus provide this sub-discipline with a framework for mutual comprehension and dialogue. And these empirical concepts, because they are so close to the data, merge easily into new and revised holistic and hermeneutic intuitive understandings of the local society under study. And such a revised, holistic total understanding of a society - one that incorporates the new empirical concepts - is clearly an

\footnotetext{
${ }^{45}$ It should be noted that the philosophical debate about "natural kinds" (initiated by Quine's paper "Natural Kinds", in his Ontological Relativity and Other Essays (New York: Columbia University Press 1969), pp. 114-138) is of only marginal relevance to the discussion of "naturalness" in this paragraph. This is because Quine's (and his interlocutors') "natural kinds" are in nature, or in the world, whereas the "natural kinds" discussed above are in the sources. (An analogy: the blind spot in the human visual field, though a "natural kind" of perception, clearly does not correspond to a "natural kind" in whatever it is that we see!) So there is no suggestion here that the "natural" categories arrived at as a first-order, rough-andready set of ad hoc meta-linguistic working tools correspond in any way to some supposed social ontology of simplest or most elementary processes or entities to which all social processes (in this society or more generally) could be reduced. On the contrary, our empirical emphasis precludes all discussion of "social ontology" (e.g. whether it is individuals or some social entities that are ultimately "real") as they are pursued in so many distinguished recent works of social philosophy (e.g. Philip Pettit, The Common Mind: An Essay on Psychology, Society, and Politics (Oxford: Oxford University Press 1993), Finn Collin, Social Reality (London: Routledge 1997), David Weissman, A Social Ontology (New Haven, CT: Yale University Press 2000), or the recent collection edited by Uskali Mäki, The Economic World View: Studies in the Ontology of Economics (Cambridge: Cambridge University Press 2001). We prefer, rather, to regard such questions, in the style of Rudolf Carnap (“Empiricism, Semantics, and Ontology”, Revue International de Philosophie 4 (1950), pp. 20-40), as "external" questions of language choice, which are not intrinsically philosophical or metaphysical questions but entirely practical. The only assumption we make here is that two kinds of practical question can be distinguished: (a) What categories can we all agree on as reasonably obvious or unproblematic? and (b) What categories are most useful or suitable from a theoretical persepective we might ultimately, down the road, want to adopt?

${ }^{46}$ See notes 29-31 above. Although critics of the Laslett-Hammel scheme often accuse it of imposing an "English" framework on households of other cultures, it is striking how such critics themselves make use of it to point out weaknesses in Peter Laslett's other ideas (e.g. relating to household zones within Europe). The alternative classification schemes advocated by critics are invariably specific to the culture they themselves are studying and hence fail to be widely adopted. The Laslett-Hammel classification scheme has been applied to households in practically every world culture for which census-type data are available, suggesting that it is in important ways more "neutral" than other possible classifications.
} 
improvement on the original, quantitatively untested one. The new one contains or accommodates more information in just the sense that a revised theory in physical or biological science contains or accommodates more information than its predecessor. ${ }^{47}$

An improved intuitive "feel" for the society is not a "theory", of course, in the sense this word is used in most sciences. The islands of precision are still tiny in the vast seas of intuition. But it is a better, more informed understanding of the society in question. Some of its vague intimations have been replaced by better defined and more precise or explicit concepts. The difference is like the improvement in medical understanding that comes from replacing vague, imprecise intuitive concepts of bodily functioning by the empirically more robust ones of biology and medical science. Though the abstract concepts of these sciences derive their meanings from their place in formalized, theoretical systems, they are learned by the aspirant doctor in such a way that they are integrated into her everyday practice. In the process of medical education these precise concepts are assimilated into her intuitions, and become part of the practical reason she applies to every diagnosis and every treatment. ${ }^{48}$

An original intuitive, holistic "feel" for a society is thus confronted with quantitative data, and revised to accommodate those data, sometimes with the addition of new empirical concepts defined directly on the basis of data. What makes the micro-exemplary method dialectical (in a Platonic, not a Hegelian sense $^{49}$ ) is the openness of this inquiry process to continued iteration. The intuitive understanding of a

\footnotetext{
${ }^{47}$ It is fashionable now to dismiss the idea that one scientific theory could be "superior" in any way to its predecessors. Theories are held, in this view, to be strictly "incommensurable" in the sense of Thomas Kuhn, The Structure of Scientific Revolutions (Chicago: University of Chicago Press 1970), and thus not comparable. Kuhn himself did not, of course, believe this; indeed he offered a list of criteria for theory choice in his paper "Objectivity, Value Judgement, and Theory Choice”, first published as Chapter 13 of his collection The Essential Tension (Chicago: University of Chicago Press 1977), pp. 320-339. Certainly it is - at least - possible to compare theories for practical usefulness, e.g. in medicine (see next footnote); this is all we require here.

${ }^{48}$ It is in this practical sense - that the modern doctor's science-acculturated intuitions are more likely to result in a cure than the medieval doctor's - that one intuitive understanding can, ultimately, be called "better" than another. The additional complication in history is that, unlike medicine, history does not have a single widely agreed-on practical use. It has many, and the criteria of usefulness might turn out to be different for these different uses. We suspect that the criteria would actually turn out to be surprisingly convergent for a wide range of uses, but this is not the forum to make that case. ${ }^{49}$ Hegelian (and Marxian) dialectic is attributed to the world, the historical process itself, from whence reason can infer it because the process is itself in accordance with (and for Hegel, an emanation of) reason. Platonic dialectic, in contrast, is a strategy for gaining knowledge; it is not imputed to the object of knowledge. It is the inquiry concerning first principles. Platonic dialectic is iterative because each science takes its first principles as given, and works with them, treats them as internal, until a breakdown occurs and they turn out no longer to be adequate; at that point, dialectic must supply new or revised ones that are also consistent with all other principles; P. Natorp, Platos Ideenlehre: Eine Einführung in den Idealismus, 2nd ed. (Leipzig: Meiner 1921), pp. 63ff.; I. Mueller, "Mathematical Method and Philosophical Truth” in R. Kraut, ed. The Cambridge Companion to Plato (Cambridge: Cambridge Universtiy Press 1992), esp. pp. 183-194. A more up-to-date way of portraying this iterative inquiry into first principles is the early Hans Reichenbach's proposal (recently revived by Michael Friedman) to regard Kantian synthetic a priori principles as provisional or conventional; see
} 
society is disciplined by quantitative tests, and is then replaced with a revised understanding incorporating new immanent or new ad-hoc empirical concepts. This process is progressive in the sense that the amount of information accommodated by it increases with each iteration; the ad-hoc empirical concepts devised in response to it become more robust each time around. They may even converge sufficiently to become the basis for convergence at a more abstract, theoretical level. ${ }^{50}$ But the dialectical process also remains open-ended; there is no end point at which understanding could be demonstrably complete. We can never exclude the possibility that a historian's ingenuity can find some new way of putting the latest, most revised understanding of a certain society to a quantitative test.

Even if all the well-known obstacles could be overcome, then, and the social sciences one day defy all predictions and become a theoretically unified discipline, the intuitive, hermeneutic "feel" for a society resulting from immersion in it would continue to be indispensable, just as a medical doctor's intuition continues to be indispensable, however scientifically educated this intuition becomes. However many aspects of a hermeneutic understanding may in future be capable of theoretical explication, the overall qualitative understanding incorporating these explications would still, just as in medicine, be essential for applying the theory in particular cases. But there is a further reason why hermeneutic understanding is inexhaustible, specifically in history. Unlike medicine, history does not have a single, clearly-defined or widely agreed practical purpose. So even if history - improbably - became a theoretical discipline, in place of its current reliance on ordinary language, the task of choosing the appropriate theoretical language (for all of history or for a particular investigation) could not be accomplished once for all. It would remain to be done over with each new investigation. And the choice of theoretical language is a practical question like any other. It is undertaken within the framework of ordinary language and its looser, more impressionistic concepts. In particular, it is undertaken against the background of our disciplined and educated hermeneutic understanding of the society under study. For this reason alone, then, the overall qualitative understanding of a society is strictly inexhaustible. ${ }^{51}$ It can never be reduced

Reichenbach's Relativitätstheorie und Erkenntnis Apriori (Berlin: Springer 1920). When Raynaud points out that Weber's epistemology of social science is "une méthodologie antidialectique", he means Hegelian (or Marxian) dialectic, as he later clarifies; "la méthode des types idéaux est d'abord anti-hégélienne” (Max Weber, p. 51). In the Platonic sense, Weber's methodology is (in contrast to, say, Durkheim’s) paradigmatically dialectical.

${ }^{50}$ In the literature on methodology of the social sciences, this level is almost invariably over-rated as a starting point for historical and social-scientific inquiry, e.g. by Karl Popper, "The Logic of the Social Sciences”, in T.W. Adorno, ed., The Positivism Dispute in German Sociology (London: Heinemann 1976), pp. 87-104. But recognition that this is an exaggeration should not blind us to the possibility that, on the basis of robust empirical concepts, interesting theories may, eventually, become feasible even in social science.

${ }^{51}$ The idea that our choice of languages for science (and, of course, our meta-language for talking about science) is, ultimately, itself a practical (normative) choice was central to the late writings of Rudolf Carnap (e.g. "Empiricism, Semantics, and Ontology"). Though this Carnapian view was widely rejected by later analytic philosophers following Quine, 
to the sum of its partial explications by theoretical concepts. There is no need, then, for historians to fear the encroachment of precise, quantitative, "scientific" concepts on a formerly "humanistic" territory; such concepts can only expand the dominion and the reach of history. They can never overrun its borders or threaten its territorial integrity, but are inherently peaceful, law-abiding subjects and citizens.

\section{The Micro-Exemplary Approach in Practice}

The above description of the micro-exemplary method is not motivated by abstract considerations of methodological or philosophical hygiene; it is an after-the-fact reconstruction of an existing, very lively and diverse, tradition of concrete historical research. And any general description like that just given is bound to be somewhat idealized; it will stress what the historians working in this tradition have in common, rather than exhibiting their very diverse particular interests and ideas. In this section, we proceed to give examples. They are not chosen at random, of course, but to illustrate the points we have been making above, and to show how widely applicable the micro-exemplary method is.

One of the first projects systematically employing the micro-exemplary approach was Richard Smith's 1974 study "English Peasant Life-Cycles and Socio-Economic Networks", which issued in a whole series of publications on inheritance, land markets, demographic trends, and social networks over the ensuing decades. ${ }^{52}$ Like Laslett, Smith was not interested in writing a "total history", but had specific hypotheses to test about medieval peasants (arising mainly from the historiography of medieval England and from the "peasant studies" literature centred around the ideas of Alexander Chayanov, Robert Redfield, Eric Wolf, and George Foster). ${ }^{53}$ Beyond testing these specific hypotheses, he wanted also

there are signs of a gradual return to Carnap in this respect; see H. Stein, "Was Carnap Entirely Wrong, After All?" Synthese 93 (1992), pp. 275-295; G. Bird, "Carnap and Quine: Internal and External Questions” Erkenntnis 42 (1995), pp. 41-64, as well as a number of contributions to the recent volume S. Awodey and C. Klein, eds., Carnap Brought Home: The View from Jena (LaSalle, IL: Open Court 2004), esp. A. W. Carus, "Sellars, Carnap, and the Logical Space of Reasons", ibid., pp. 317-351.

${ }^{52}$ R.M. Smith, "English Peasant Life-Cycles and Socio-Economic Networks: a Quantitative Geographical Case Study" (Ph.D. Dissertation, University of Cambridge, 1974); R.M. Smith, "Kin and Neighbours in a Thirteenth Century Suffolk Community", Journal of Family History, 4 (1979), pp. 219-56; R.M. Smith, “Some Thoughts on 'Hereditary' and 'Proprietary' Rights in Land under Customary Law in Thirteenth and Early Fourteenth Century England”, Law and History Review, 1 (1983), 95-128; R.M. Smith, "Families and Their Land in an Area of Partible Inheritance: Redgrave, Suffolk 1260-1320”, in R.M. Smith, ed., Land, Kinship and Life-Cycle (Cambridge: Cambridge University Press, 1984), 135-96, here pp. 193-4; R.M. Smith, "Social Groupings and their Relationships in a Suffolk Market Settlement 1260-1320"; R.M. Smith, “Coping with Uncertainty: Women’s Tenure of Customary Land in England c. 1370-1430”, in J. Kermode, ed., Enterprise and Individuals in Fifteenth-Century England (Stroud, 1991), pp. 43-67.

${ }^{53}$ Smith, "English Peasant Life-Cycles", pp. 5, 9-10, 101-49. 
"to establish quantitative variables capable of being used for objective regionalization of medieval rural society". 54

From the beginning, Smith recognized that the questions he was addressing could only fruitfully be studied within the framework of a relatively small "community" - in this case not a single settlement but the dispersed population of hamlets and farms over which the Redgrave and Rickinghall manorial courts in Suffolk had jurisdiction. ${ }^{55}$ This was partly because these questions required an understanding of the local ecology, institutional practices, and social structure. But it was also partly because generating the "quantitative variables" he desired required linking different qualitative sources referring to the same individual (e.g. manorial survey entries with manorial court cases), which resource constraints dictated could only be done for a relatively small group and time-period. ${ }^{56}$

Smith's first step was, in effect, to create a set of empirical concepts of his own that arose directly from, and stayed close to, the available sources. He used not only the traditional medievalist's sources - tax documents, manorial extents, compotus rolls, and charters, ${ }^{57}$ but also manorial court rolls, which were more likely than other documents to record less well-off social groups, but had never "been used in a systematic, let alone scientific fashion" ${ }^{58}$ He extracted all persons named in these records, noting all relationships among different persons, and linking all references to the same person across different documents. ${ }^{59}$ Smith thus created a "meta-source" consisting of all observed persons, their relationships with one another, and their involvement in particular transactions and conflicts. The organization of the concepts in this meta-source was sufficiently neutral that he was not only able to use them to confront the disparate hypotheses he had begun with, but could then also use the same data to ask questions ranging far beyond those for which it was originally collected, ultimately using it to analyse kinship and neighbourliness, ${ }^{60}$ inheritance, ${ }^{61}$ customary law, ${ }^{62}$ landholding,${ }^{63}$ seigneurial strategies, ${ }^{64}$ social stratification, ${ }^{65}$ and women's economic position. ${ }^{66}$

\footnotetext{
${ }^{54}$ Smith, "English Peasant Life-Cycles", p. 1.

${ }^{55}$ Smith, "English Peasant Life-Cycles", p. 2, 11-14; Smith, "Families and Their Land", p. 138.

${ }^{56}$ Smith, "English Peasant Life-Cycles", p. 4; Smith, "Families and Their Land”, pp. 144-6.

${ }^{57}$ Smith, "English Peasant Life-Cycles", p. 2; Smith, "Families and Their Land", pp. 138-46.

${ }^{58}$ Smith, "English Peasant Life-Cycles", p. 2.

${ }^{59}$ Smith, "Families and Their Land", pp. 144-6.

${ }^{60}$ Smith, Richard M., "Kin and Neighbours".

${ }^{61}$ Smith, "Families and Their Land".

${ }^{62}$ Smith, "Some Thoughts".

${ }^{63}$ Smith, "Families and Their Land".

${ }^{64}$ Smith, "Some Thoughts", esp. pp. 114-19.

${ }^{65}$ Smith, Richard M., "Social Groupings".
} 
Using the micro-exemplary approach, Smith was able to achieve a fundamental reappraisal of existing theories about medieval peasants. Medievalists and peasant theorists alike had assumed that peasants had strong family ties to the land, a weak sense of private property, and little market involvement. But Smith found that the sanctity of the family holding was hardly in evidence. Much land was held and sold individually, he discovered, with a substantial proportion of market sales of land to non-kin even when inheriting kin were available. ${ }^{67}$ Such findings, which could only have been generated through his innovative method for transforming the qualitative data contained in court rolls and land surveys into a "meta-source" that could be analyzed quantitatively, fundamentally changed existing views of the medieval economy which had been based on theory or qualitative impressions alone. ${ }^{68}$

The same approach was used by Keith Wrightson and David Levine in their 1979 study of the Essex village of Terling. ${ }^{69}$ Their questions differed from Smith's. They began by investigating illegitimacy, but "the subject of our initial investigation was gradually subsumed within a larger, more comprehensive framework" ${ }^{70}$ They describe this dialectical interaction between data and theory as follows:

... it was never our intention to write "total history". We came to our task with certain questions in mind. In seeking answers, however, we let the records speak to us. As our work progressed, our range of questions and of source materials grew. The emerging picture of society in Terling sometimes crystallized and confirmed, sometimes modified or challenged the ideas and prejudices of our earlier work ... ${ }^{71}$

This was possible precisely because of the methodology they adopted. Their first step was, like Smith, to select a particular community with a population small enough (at 300-600 inhabitants) to make it possible to extract all individuals from surviving documents for the community over a period of nearly two centuries, reconstruct the relationships between them, record other characteristics of these individuals (wealth, social stratum, religious dissent, demographic behaviour), and then link all references to each individual across documents. ${ }^{72}$ The "meta-source" was compiled in a sufficiently

\footnotetext{
${ }^{66}$ Smith, Richard M., "Coping with Uncertainty".

${ }^{67}$ Smith, "English Peasant Life-Cycles", p. 131; see also Smith, "Families and Their Land”, pp. 149-86.

${ }^{68}$ Phillipp R. Schofield, in his textbook Peasant and Community in Medieval England, 1200-1500(London: Palgrave 2003) assigns central importance (e.g. pp. 2-3) to Smith's work in revealing the commercial nature of the English medieval economy, and thus in the overthrow of the previously established Chayanovian view.

${ }^{69}$ Wrightson and Levine, Poverty and Piety.

${ }^{70}$ Wrightson and Levine, Poverty and Piety, p. ix.

${ }^{71}$ Wrightson and Levine, Poverty and Piety, p. $\mathrm{x}$.

${ }^{72}$ Wrightson and Levine, Poverty and Piety, pp. ix-x, 45.
} 
neutral way that the researchers could eventually ask questions relating not just to demography - their initial interest - but also wealth, migration, conflict, education, and religion.

The micro-exemplary method led the two researchers to a whole array of striking and pathbreaking findings. Counter to traditional views of the importance of kinship in pre-industrial society, linking family reconstitution data with tax records and wills showed that Terling's kin links were narrow and loose compared to historic French and modern English villages. ${ }^{73}$ Counter to traditional theories that pre-modern farmers felt a strong attachment to the family farm, Wrightson and Levine found that market sales were nearly as important as inheritance and few landholdings stayed in the family for more than two generations. ${ }^{74}$ And counter to traditional views of closed and immobile rural communities, Wrightson and Levine's innovative mapping of transaction partners showed that in almost every aspect of life a non-trivial percentage of villagers' interactions were with outsiders. ${ }^{75}$ They were even able to cast light on traditional views of Puritanism, showing much higher levels of religious dissent among respectable householders than in the lower village strata, who manifested widespread religious indifference. ${ }^{76}$ These findings could not have been obtained simply by immersing oneself in the impressions gained from qualitative sources: it was necessary to turn qualitative documents - parish registers, wills, land transactions, recognizance bonds, mortgage indentures, court records - into a "meta-source" that could be analysed quantitatively, in order to find out how widespread certain activities were, whether in the village at large or among particular social groups. Wrightson and Levine’s findings concerning kinship and religion outraged many historians who had relied on qualitative sources alone, but have proved remarkably robust as additional data have emerged for Terling and other early modern English villages. ${ }^{77}$

As these two studies were proceeding, a larger-scale project was in the works that spectacularly illustrates the methodological procedure of creating a "meta-source" of empirical concepts, capable of quantitative analysis, and using it in dialectical interplay to test questions arising from the qualitative sources themselves. In 1963, Tony Wrigley chose the Devon parish of Colyton as the first English village to be subjected to Henry's technique of family reconstitution. Wrigley's initial aim was to test

\footnotetext{
${ }^{73}$ Wrightson and Levine, Poverty and Piety, pp. 82-94.

${ }^{74}$ Wrightson and Levine, Poverty and Piety, pp. 29-31.

${ }^{75}$ Wrightson and Levine, Poverty and Piety, pp. 48, 69, 75-82.

${ }^{76}$ Wrightson and Levine, Poverty and Piety, pp. 165-72.

${ }^{77}$ See the quiet but persuasive re-assessment of the "Terling thesis" in K. Wrightson, "Postscript: Terling Revisited", in Wrightson and Levine, Poverty and Piety (2nd expanded edn), pp. 197-220.
} 
theories about pre-industrial demographic behaviour, arising partly out of the discipline of demography but also partly from the reading of other qualitative sources on pre-industrial English family structure by his colleague Peter Laslett. ${ }^{78}$ Questions about nuptiality, fertility, fertility limitation, and mortality could only be answered through micro-level approaches since they required transcribing baptisms, weddings, and burials, indexing them, and linking them by name and other characteristics - the famously labour-intensive "family reconstitution" technique which, even now that it has been computerized, still encounters serious resource constraints when attempted for larger populations over longer time-periods.

But Colyton was not destined to remain a simple reconstitution study. Over the years, both the original researchers and others who followed them compiled, added, and linked to the family reconstitution a whole array of additional historical documents relating to the parish - inventories, tax documents, poor relief accounts, wills, estate surveys, court records, and many more. One important aspect of this operation was to attach one of four social status designations to each individual and family in the community: this involved the systematic transformation of qualitative into quantitative data, using a hierarchy of criteria beginning with wealth indicators, but then resorting to qualitative indicators such as occupation, landownership, inventoried possessions, wages received, taxes paid, receipt of poor relief, or having children put into pauper apprenticeship. ${ }^{79}$

As a result, what started out as a purely demographic family reconstitution gradually turned into a multifaceted and continually expanding database which could be used to address a broad array of questions about English society between the sixteenth and twentieth centuries: nuptiality, ${ }^{80}$ marital separation, ${ }^{81}$ migration, ${ }^{82}$ ageing, ${ }^{83}$ disease,${ }^{84}$ baptism practices,${ }^{85}$ childrearing, ${ }^{86}$ religious dissent,${ }^{87}$ childhood, ${ }^{88}$

\footnotetext{
${ }^{78}$ See esp. E.A. Wrigley, “Family Limitation in Pre-Industrial England”, Economic History Review, 2nd ser. 19 (1966), pp. 82-109; E.A. Wrigley, "Mortality in Pre-Industrial England: the Example of Colyton, Devon, over Three Centuries”, Daedalus, 97 (1968), pp. 546-580.

${ }^{79}$ P. Sharpe, Population and Society in an East Devon Parish: Reproducing Colyton 1540-1840 (University of Exeter Press, 2002), pp. 318-325.

${ }^{80}$ P. Sharpe, "Literally Spinsters: a New Interpretation of Local Economy and Demography in Colyton in the Seventeenth and Eighteenth centuries", Economic History Review, 44 (1991), pp. 46-65; P. Sharpe, Population and Society, esp. pp. 161-207, 274-279.

${ }^{81}$ Sharpe, Population and Society, esp. pp. 290-294.

${ }^{82}$ R.S. Schofield, “Age-Specific Mobility in an Eighteenth-Century Rural English Parish”, Annales de Démographie Historique, (1970), 261-274; E.A. Wrigley, “A Note on the Life-Time Mobility of Married Women in a Parish Population in the Later Eighteenth Century”, Local Population Studies, 18 (1977), pp. 22-29; Sharpe, Population and Society, esp. pp. 161-207.

${ }^{83}$ J. Robin, "Family Care of the Elderly in a Nineteenth-Century Devonshire Parish", Ageing and Society, 4:4 (1984), pp. 505-516; Sharpe, Population and Society, esp. pp. 295-299.
} 
poverty, ${ }^{89}$ welfare provision, ${ }^{90}$ occupational structure,${ }^{91}$ agricultural practice, ${ }^{92}$ proto-industry, ${ }^{93}$ apprenticeship, ${ }^{94}$ women's work, ${ }^{95}$ domestic service, ${ }^{96}$ and social class. ${ }^{97}$ Cross-linking new sources to the family reconstitution also enriched the demographic questions that could be addressed, e.g. how demographic behaviour varied with social stratum, wealth and occupation. ${ }^{98}$

This transformation of the qualitative sources for Colyton into a meta-source that could be analysed quantitatively, and the extension of the meta-source over four decades, generated striking findings which transformed many historical debates. The original family reconstitution for Colyton, for instance, generated the astonishing revelation that seventeenth-century couples were already deliberately limiting their fertility, long before the "demographic transition" of the nineteenth century. ${ }^{99}$ Another striking finding emerged in the 1990s when Pamela Sharpe found that, counter to traditional assumptions, marriage rates could sometimes be more strongly influenced by women's than by men's

\footnotetext{
${ }^{84}$ R.S. Schofield, “An Anatomy of an Epidemic - Colyton, November 1645 to November 1646”, in Local Population Studies Supplement, ed., The Plague Revisited (Matlock, 1977), pp. 95-126.

${ }^{85}$ E.A. Wrigley, "Baptism Coverage in Early Nineteenth-Century England: the Colyton Area", Population Studies, 29 (1975), 299-316.

${ }^{86}$ Sharpe, Population and Society, esp. pp. 252-256.

${ }^{87}$ Sharpe, Population and Society, esp. pp. 29-64.

${ }^{88}$ P. Sharpe, "Poor Children as Apprentices in Colyton, 1598-1830", Continuity and Change, 6 (1991).

${ }^{89}$ Sharpe, Population and Society, esp. pp. 208-249; Sharpe, "Poor Children as Apprentices".

${ }^{90}$ Robin, "Family Care of the Elderly"; J. Robin, "The Relief of Poverty in Mid-Nineteenth Century Colyton", Rural History, 1 (1990), pp. 193-218; Sharpe, "Poor Children as Apprentices"; Sharpe, Population and Society, esp. pp. 208249.

${ }^{91}$ E.A. Wrigley, "The Changing Occupational Structure of Colyton over Two Centuries", Local Population Studies, 18 (1977), pp. 9-21.

${ }^{92}$ Sharpe, Population and Society, esp. pp. 120-159.

${ }^{93}$ Sharpe, "Literally Spinsters"; Sharpe, Population and Society, esp. pp. 67-119.

${ }^{94}$ Sharpe, “Poor Children as Apprentices”; Sharpe, Population and Society, esp. pp. 256-270.

${ }^{95}$ Sharpe, "Literally Spinsters".

${ }^{96}$ Sharpe, Population and Society, esp. pp. 271-273.

${ }^{97}$ P. Sharpe, “The Total Reconstitution Method: a Tool for Class-Specific study?”, Local Population Studies, 44 (1990), pp. 41-51.

${ }^{98}$ E.A. Wrigley, "Marital Fertility in Seventeenth-Century Colyton: A Note", Economic History Review, 31 (1978), pp. 429-36; Wrigley, "Baptism Coverage"; Schofield, “An Anatomy of an Epidemic"; J. Robin, "Prenuptial Pregnancy in a Rural Area of Devonshire in the Mid-Nineteenth Century: Colyton 1851-1881", Continuity and Change, 1:1 (1986), pp. 113-124; J. Robin, "Illegitimacy in Colyton 1851-1881", Continuity and Change, 2:2 (1987), pp. 307-342; Sharpe, Population and Society, esp. pp. 161-207, 279-289; R.T. Vann, "Unnatural Fertility, or Whatever Happened in Colyton? Some Reflections on English Population History from Family Reconstitution 1580-1837”, Continuity and Change, 14 (1999), pp. 91-104.

${ }^{99}$ Wrigley, "Family Limitation". Although these findings evoked some debate in the 1970 s (see esp. R.B. Morrow, "Family Limitation in Pre-Industrial England: A Reappraisal", Economic History Review, 31 (1978), pp. 419-436, and the reply by Wrigley, "Marital Fertility"), other studies strongly supported them (see esp. N. F. R. Crafts and N. J. Ireland, "Family Limitation and the English Demographic Revolution: A Simulation Approach", Journal of Economic History, 36 (1976), pp. 598-623). The most recent consensus is that family limitation was present in late seventeenth-century and early eighteenth-century Colyton among certain social strata, as well as in some other early modern English communities (see the discussion in Sharpe, Population and Society, pp. 189-197).
} 
wages and that proto-industrial activity could reduce rather than encouraging nuptiality by offering women attractive non-domestic livelihoods. ${ }^{100}$ Neither finding could have been made without transforming qualitative sources into a community-level interlinked "meta-source" which could be interrogated quantitatively over a series of decades by historians with very different theoretical preoccupations. No doubt the Colyton database will be used in future to address questions that historians have not yet devised.

From these English beginnings, the application of the micro-exemplary style of research has spread to many other kinds of society. One early example was its application to the Piedmontese village of Alagna by Paulo Viazzo. ${ }^{101}$ As in the English cases just mentioned, Viazzo began with questions raised by qualitative research, and then created a "meta-source" capable of quantitative analysis. The qualitative research, in this case, was 18 months of anthropological fieldwork between 1979 and 1981 in Alagna, which was a Walser (i.e. German-speaking) community in the Italian Alps. Viazzo's initial question related to ethnic change, arising from anthropologists' interest in cultural frontiers. ${ }^{102}$ But he soon realised that his fieldwork also shed light on the quite different issue of "relations between the physical environment and human social organization", something of equal concern to anthropologists interested in closed corporate communities and demographers (or geographers) interested in the balance between population and resources. ${ }^{103}$ For two reasons, this question was best studied at the community level: first, environmental management is most appropriately examined at the interface where individual human beings interact with ecological constraints; and second, the community itself is generally viewed as the key institution for managing environmental resources.

Viazzo's approach resembled other applications of the micro-exemplary method by combining different sources of qualitative evidence into a database that could be explored quantitatively. He began with qualitative data collected in his anthropological fieldwork in 1979-81 - interviews and an informal village census - but then added parish registers, village censuses, and descriptive sources dating from the fifteenth to the twentieth century. ${ }^{104}$ This methodological decision was guided by his realisation, based on the qualitative data, that the balance between humans and the natural environment was a

\footnotetext{
${ }^{100}$ Sharpe, "Literally Spinsters".

${ }^{101}$ P.P. Viazzo, Upland Communities: Environment, Population and Social Structure in the Alps since the Sixteenth Century (Cambridge: Cambridge University Press, 1989).

${ }^{102}$ P.P. Viazzo, "Ethnic Change in a Walser Community in the Italian Alps" (Ph.D. Dissertation, University of London, 1983).

${ }^{103}$ Viazzo, Upland Communities, pp. 1-15.

${ }^{104}$ Viazzo, Upland Communities, pp. 6-7, 9-11, 127-35.
} 
question that required a long-term historical perspective. It was also based on a realisation that his informants' statements in 1979-81 about traditional household structures were at odds with the evidence emerging from the quantitative analysis of village censuses. ${ }^{105}$ The meta-source Viazzo compiled from qualitative data subsequently proved susceptible to quantitative analysis not just to address questions of inter-ethnic and class relations, but also family structure, ${ }^{106}$ marriage patterns, ${ }^{107}$ illegitimacy, ${ }^{108}$ communal institutions, ${ }^{109}$ and "environmental history". ${ }^{110}$

The micro-exemplary approach enabled Viazzo to find that, counter to traditional assumptions, Alpine communities did not stay in balance with their environment only through permanent emigration. He showed that ecological balance had long been managed primarily through late marriage, high lifetime celibacy, seasonal emigration, and low fertility. ${ }^{111}$ Counter to models of Alpine communities as "autarkic" and closed, Viazzo showed that they were often more closely integrated into the wider economy than were villages lower down. ${ }^{112}$ His transmutation of qualitative into quantitative data for the village of Alagna, and his sophisticated and wide-ranging comparison of these findings with those for other villages throughout the Alps over a period of centuries, enabled Viazzo to cast serious doubt on both ecologically and culturally deterministic accounts of Alpine demography and institutions.

Another well-known application of the micro-exemplary approach outside England is Hans Medick's 1996 study of the southwest German community of Laichingen. Like Viazzo’s study it shows how this approach can be used to explore not just the demographic, social, and economic questions for which it has so often been used, but quite different fields - in this case cultural history. ${ }^{113}$ Medick began his Laichingen research in the later 1970s with the aim of exploring how "proto-industrialization" export-oriented rural industry - affected demographic and economic life. ${ }^{114}$ This question arose mainly from the theoretical debate about proto-industrialization, to which Medick himself had significantly

\footnotetext{
${ }^{105}$ Viazzo, Upland Communities, pp. 13-14, 95-7.

${ }^{106}$ D. Albera, and P.P. Viazzo, “The Peasant Family in Northern Italy, 1750-1930: A Reassessment”, Journal of Family History, 15 (1990), pp. 461-482.

${ }^{107}$ P.P. Viazzo, and D. Albera, "Population, Resources and Homeostatic Regulation in the Alps: the Role of Nuptiality", in M. Mattmüller, ed., Wirtschaft und Gesellschaft in Berggebieten (Basel, 1986), pp. 182-231.

${ }^{108}$ P.P. Viazzo, "Illegitimacy and the European Marriage Pattern: Comparative Evidence from the Alpine Area", in L. Bonfield, R.M. Smith, and K. Wrightson, eds., The World We Have Gained: Histories of Population and Social Structure (Oxford: Oxford University Press, 1986), 100-21.

${ }^{109}$ Viazzo, Upland Communities, pp. 276-85.

${ }^{110}$ Viazzo, Upland Communities, pp. 1-5, 27-8, 113, 119, 221-2, 277-8, 264.

${ }^{111}$ Viazzo, Upland Communities, esp. chs. 4, 8, and 10.

${ }^{112}$ Viazzo, Upland Communities, pp. 276-85.

${ }^{113}$ H. Medick, Weben und Überleben.

${ }^{114}$ Medick, Weben und Überleben, pp.16-19.
} 
contributed. ${ }^{115}$ In response to what he found in the qualitative sources for the village, however, Medick expanded his perspective to explore cultural questions such as responses to famine and bookownership, confounding cultural historians by finding levels of book-ownership in inventories of modest villagers that rivalled those observed in the capital city of Stuttgart.

Medick's community micro-study approach followed the pattern of Smith, Wrightson and Levine, the Colyton researchers, and Viazzo: focussing on a single community, creating a database of all individuals and relationships within it using qualitative evidence from a wide range of historical sources, and then using this database as a meta-source which could be analysed both qualitatively and quantitatively. ${ }^{116}$ And once again, the concepts of the meta-source were sufficiently close to the data, sufficiently neutral, that it could be used to address questions radically different from those for which it was originally compiled. $^{117}$

In all these cases, the basic demographic, household, tax and/or property data for the community under study form the quantitative backbone of the "meta-source" that was created. Our final example of the micro-exemplary method in action pushes this idea of creating a "meta-source" of data-generated concepts one step further; here the qualitative source that formed the basis for generating quantitative evidence was more "purely" qualitative, in the sense that it did not occur (as does a parish register, a tax list, or a cataster) in the form of a list or of serial, discrete, repetitive units that - though qualitative fall into obvious "natural" sets ready-made for counting. In this final case there was not, on the surface, anything obvious to count; there was nothing "naturally" countable (in the sense of Section 3 above).

The study in question was recently undertaken - by one of the present authors - to gain a better understanding of women's work in pre-industrial society. ${ }^{118}$ This subject has long been studied by impressionistic methods using literary or other qualitative evidence, and it has seemed all but impossible to penetrate the barriers of near-invisibility in which the female half of the pre-industrial population has been shrouded. To overcome this problem, it was decided - in micro-exemplary style to focus on a social unit that could be circumscribed reasonably easily, in this case the small district of Wildberg in the Württemberg Black Forest, consisting of ten communities with a combined population

\footnotetext{
${ }^{115}$ Kriedte, Medick, and Schlumbohm, Industrialisation before Industrialisation.

${ }^{116}$ Medick, Weben und Überleben, pp. 19, 26, 28.

${ }^{117}$ Medick, Weben und Überleben, pp. 26-8.

${ }^{118}$ The results of this study are to be found in S. Ogilvie, A Bitter Living: Women, Markets, and Social Capital in Early Modern Germany (Oxford: Oxford University Press, 2003). The following pages of this section draw heavily on that book.
} 
of about 5,000 persons in the seventeenth and eighteenth centuries. Detailed reading of one particular source for these communities - the church-court minutes - revealed that they contained many references to women's economic activities. To turn this rich qualitative source into quantitative evidence that could be used to test our intuitive understanding of this society, all references to work by both sexes were extracted from the over 7,000 handwritten pages of church court minutes for two communities of the district, the small town of Wildberg (population 1,200-1,400) and the village of Ebhausen (population 600-900). This required the adoption of certain conventions. Only actual references to actual work behaviour were noted, not references to occupations or crafts, partly because it was thought that these would very likely be biased toward males, who would be more likely to be formally designated as holding occupations, though not (as was known from informal acquaintance with these records) more likely actually to be doing the corresponding work). ${ }^{119}$

This resulted in a data set of 2,828 observations of people working. These data did not, of course, represent a complete picture of time allocation in this society; they were a sample. But like any statistical sample, this one could be tested for representativeness and robustness in various ways. For one thing, the observations all came from the same society, so the social and economic environment was held constant. Certainly, the church court data set was influenced (to some degree) by the fact that testimony was given under conditions of stress or conflict, in the somewhat unnaturally formal context of a court meeting (normally presided over by the pastor, with three or four fellow citizens also present). However, these same conditions also guaranteed that information not under dispute and peripheral to the case (as the information relating to work being done by accusers, accused, or witnesses generally was) was unlikely to be fabricated or merely subjective, as it was validated (considered at least plausible) by all present at the proceedings. So there was no reason to believe that the observations of work might be systematically distorted in any particular direction, and thus no reason to believe that descriptive statistics based on it should be treated more suspiciously than, say, the results of a modern survey, which might also be thought to suffer from inherent collection and situational biases, and from the unintentionally loaded wording of questions. ${ }^{120}$

There are, however, two considerations that make a meta-source of this kind more problematic than the previous examples cited in this section. First, there is the problem already mentioned: court records

\footnotetext{
${ }^{119}$ For other conventions adopted in extracting this data, see Ogilvie, A Bitter Living, pp. 24-26 and p. 29.

${ }^{120}$ Inference from survey data, and the use of survey statistics, is discussed in M. Rosenberg, The Logic of Survey Analysis (New York: Basic Books 1968).
} 
are not, on the surface, "naturally" countable. The "units" to be counted are not clearly suggested by the physical arrangement of the source itself, therefore; their identification requires conceptual intermediation - it requires interpretation. And second, the concept whose instances are counted is a concept of our meta-language, not of the language in which the source is composed. This is also the case where we count instances of "birth", "death", and so on, but in these cases we can feel very confident, for obvious reasons, that our meta-linguistic concept overlaps closely with the corresponding concept in the object language; we need hardly fear that the extension, at least, of our meta-linguistic concept will differ much from that of the corresponding object-language concept, however much connotations may differ. ${ }^{121}$ In the case of "work" (even though it appears to correspond extensionally quite closely with the object-language concept of "Geschäft"; see below, p. 37), we have less reason to be confident, as once again a certain amount of interpretation unavoidably inserts itself between us and the raw evidence.

The solution, in the Wildberg case, was to index the meta-source to such a set of more "naturally" quantitative sources available for the same locality, in which the extensions, at least, of our metalanguage and the source language were likely to coincide. This was undertaken so as to anchor the reliability of the more problematic meta-source in those less problematic ones. A wide variety of such more obviously countable documents for this same district - parish registers, censuses, tax registers, guild account-books, court minutes - had, fortunately, been previously compiled into a very extensive database for an earlier project testing hypotheses about proto-industry, demography, and local institutions. ${ }^{122}$ If certain basic parameters from the work database matched up to what was known from the "naturally" quantitative sources whose concepts require less interpretation, it could then "borrow" its robustness and representativeness from those sources; its reliability would be "guaranteed" by them. ${ }^{123}$

\footnotetext{
${ }^{121}$ Any nominal expression may be regarded as having an extension (the objects to which it refers) and an intension (the way it refers to them). Thus "morning star" and "evening star" differ in intension but share the same extension (the planet Venus). This example is Bertrand Russell's, and the best-known version of this distinction (as that between "sense" and "reference") is due to Gottlob Frege; a similar distinction had previously been made by John Stuart Mill, who called extension "denotation" and intension "connotation". In a case like the above, it is always much easier to ascertain that the extension of a present concept coincides with that of a past one than to determine whether their intensions coincide. ${ }^{122}$ S. Ogilvie, State Corporatism and Proto-Industry: The Württemberg Black Forest 1590-1 797 (Cambridge: Cambridge University Press, 1997) and associated publications detailed in note 133 below.

${ }^{123}$ It should be stressed, once again (see above, Section 3, especially the paragraph on pp. 19-20 about the "naturalness" of first-order empirical categories in the "meta-source" and note 45), that such "naturalness" is an entirely practical and ad hoc matter, with no implications whatever about some supposed ultimate "ontology" of the society under study, which indeed we think is difficult or impossible to give any practical sense to. The comparative "naturalness" with which parish registers and church court minutes lend themselves to counting is a matter of degree, and is in any case a practical question of how easy it is to arrive at general agreement (among historians who have worked with such documents) about what one is
} 
In itself, this kind of internal cross-check among different sorts of data is nothing new; ${ }^{124}$ we find it highly developed even in the earliest of the studies discussed above. In compiling his meta-source, Richard Smith had been careful to subject to critical reflection the processes that generated the data, a particularly acute question in the case of court records, which are less standardized than other qualitative sources such as parish registers, censuses, or land surveys. ${ }^{125}$ For instance, in assessing shifts between post-mortem and inter-vivos land transfers, Smith carefully considered whether one sort of transaction was more likely to be recorded than the other, whether the frequency of court sessions was changing over time, and whether incomplete survival of court records was likely to bias the results. ${ }^{126}$ Given the inherent indeterminacy of some qualitative data - "since some kin relationships will have left no traces in the record and a certain instability in surnames is still present at this date" Smith was careful to state his results as lying between certain limits: thus "the minimum proportion of customary land so held [by the laterally extended family] was 24 per cent and the maximum 40 per cent. Some intermediate value might be a not unreasonable estimate....${ }^{127}$ Smith also cross-checked his quantitative findings against other sources, both qualitative cases from his own court rolls, and quantitative analyses of land transfers in other medieval communities. ${ }^{128}$

In Wrightson and Levine's study of Terling, the linking of data from many different sources to individual names also made it possible to check different sources against one another - for instance, to establish that all those receiving poor relief in the poor rate accounts were also included in tax lists among those excused tax on grounds of poverty. ${ }^{129}$ And in the Colyton reconstitution, the addition of new data to the demographic backbone made it possible to examine much more thoroughly whether the data resulted from uniform generating process over the period: quantitative analyses and qualitative sources could be compared to find out whether there was change over time in people's decision to

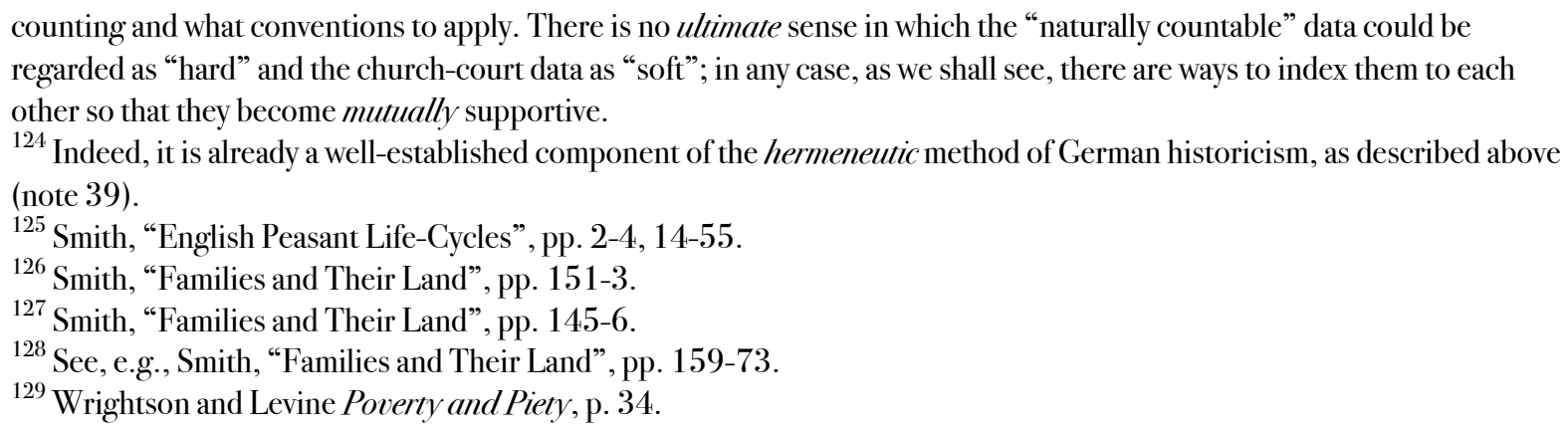


register their weddings or baptisms in the local community or in the Anglican church, and whether different social groups were equally represented in the data. ${ }^{130}$

So the indexing of the Wildberg work database to the basic demographic data merely extended a practice long established within the micro-exemplary approach. And the results were reassuring. The 2,828 work observations fell into two large categories: work prosecuted as Sabbath-breaking, and work observed "descriptively", in passing, within other sorts of case. The descriptive observations recorded women nearly in proportion to their share in the population, and while the Sabbath-breaking observations under-represented women, they revealed sectoral and spatial patterns of observed work which were strikingly similar to those in the descriptive observations. The proportion of women's work to total observations of work was tested for changes over time and remained relatively constant over the entire 150-year period of observation. The proportions of men and women in various marital and household statuses, in the work observation data, were checked against local censuses, and were found to correspond roughly to their proportions in the population. ${ }^{131}$

The nature of what was being observed was also tested against other sources of evidence. The court's regulatory concerns were inescapable, but there were several ways of checking on the extent of this bias. The immanent concept of "work" (or "business") was built into the definition of the church court's remit; the Sabbath regulations explicitly prohibited "all business [Geschäft] in house and field, inside and outside the village" ${ }^{132}$ Evidence from elsewhere in the church court minutes (and other local records) showed that the church courts possessed the means to enforce this prohibition and did so in practice. Outdoor work was more observable, but the church court's remit was very strongly focussed on familial and sexual conflicts and hence likely to be biased toward indoor activities: this means that the two biases to some extent cancelled out. In fact, both indoor and outdoor work were strongly represented in the database. The types of working activity manifested in the church court work database were compared against an outside source - a "soul-table" listing the "trade and livelihood" of all

\footnotetext{
${ }^{130}$ E.A. Wrigley, "Some Problems of Family Reconstitution using English Parish Register Material: the Example of Colyton", in Proceedings of the 3rd International Economic History Conference, Munich, 1965. Section VII, demography and economy (Paris, 1972), pp. 199-221; R.S. Schofield, "Representativeness and Family Reconstitution", Annales de Démographie Historique (1972), pp. 122-125; Sharpe, "The Total Reconstitution Method”; Sharpe, Population and Society, esp. pp. 1-28, 305-306, 313-317.

131 This is detailed in Ogilvie, A Bitter Living, Table 1.3, p. 27, and the accompanying discussion on pp. 25-29. The data for the underlying population are derived from censuses of Wildberg in 1717 and 1722.

${ }^{132}$ Only in October 1799 did the central government in Stuttgart relent, and allow the pursuit of "occupations, business, and trades" on Sundays and holidays, as long as they were not carried out during or before actual church services; Ogilvie, $A$ Bitter Living, p. 29.
} 
independent earning units in the same district in 1736 - and this comparison showed that the church court observations covered all the different sectors and individual activities listed in the soul-table.

Finally, the fact that the church court work observations extended across all sectors of the economy, registered indoor as well as outdoor work, and recorded such intimate activities as washing the parlour floor, soaking laundry at home, rolling out biscuits, serving a meal, making a fire, cleaning up drunken vomit, washing lettuce, cooking gruel for a newborn infant, boiling milk, and mending one's husband's trousers, suggested that it penetrated further into the realm of time allocation than has usually been thought possible for the invisible half of pre-industrial society.

The study of women's work based on this data set in conjunction with a large body of other qualitative and quantitative evidence ${ }^{133}$ came to conclusions that varied in many respects from those based on more impressionistic use of literary and other qualitative sources. We will not attempt to summarize those conclusions here. ${ }^{134}$ Nor is a direct comparison possible of the quality of conclusions drawn from these data based solely on immersion in the same or similar records employed only as qualitative evidence (rather than as both qualitative and quantitative evidence), as no such study has been undertaken with these sources. But an example will illustrate the gains from this new quantitative use of qualitative evidence. It has generally been thought, on the basis of (post-industrial) common sense and impressionistic use of qualitative evidence, especially from literary sources, that women's work options in pre-industrial society were constrained (a) by their physical strength, especially upper-body strength and (b) by the need to be in or near the dwelling, to care for small children and do housework, and by the limits on mobility imposed by pregnancy. ${ }^{135}$ These hypotheses lead to the prediction that we would find women much more heavily engaged in light, domestic activities (housework, child care, weaving,

\footnotetext{
${ }^{133}$ As well as against the background of a series of previous studies of the institutional structure of this same society and its larger social and economic context: S. Ogilvie, "Coming of Age in a Corporate Society: Capitalism, Pietism, and Family Authority in Rural Württemberg 1590-1740", Continuity and Change, 1 (1986), pp. 279-331; S. Ogilvie, "Women and Proto-Industrialisation in a Corporate Society: Württemberg Woollen Weaving 1590-1760”, in P. Hudson and W. R. Lee, eds., Women's Work and the Family Economy in Historical Perspective (Manchester: Manchester University Press 1990), pp. 76-103; S. Ogilvie, "Germany and the Crisis of the Seventeenth Century", Historical Journal, 35 (1992), pp. 417441; S. Ogilvie, "Institutions and Economic Development in Early Modern Central Europe: Proto-industrialisation in Württemberg, 1580-1797", Transactions of the Royal Historical Society, 6th series 5 (1995), pp. 221-250; S. Ogilvie, "Social Institutions and Proto-Industrialisation", in S. Ogilvie and M. Cerman, eds., European Proto-Industrialisation (Cambridge: Cambridge University Press 1996), pp. 23-37; S. Ogilvie, State Corporatism and Proto-Industry: the Württemberg Black Forest, 1580-1 797 (Cambridge: Cambridge University Press 1998); S. Ogilvie, "The German State: A Non-Prussian View”, in J. Brewer and E. Hellmuth, eds., Rethinking Leviathan: The Eighteenth Century in Britain and Germany (Oxford: Oxford University Press 1998), pp. 167-202.

${ }^{134}$ An overview can be found in Ogilvie, Büter Living, Chapter 7; see also S. Ogilvie, "How Does Social Capital Affect Women? Guilds and Communities in Early Modern Germany", American Historical Review, 109 (2004), pp. 325-359; S. Ogilvie, "Women and Labour Markets in Early Modern Germany", Jahrbuch für Wirtschaftsgeschichte, 2004:2 (2004). ${ }^{135}$ See the literature reviewed (and criticized) in Ogilvie, Bitter Living, pp. 7-9, and "Women and Labour Markets".
} 
etc.), than heavy, non-domestic activities such as day-labouring or agriculture. But the reverse was the case, as we know from the above-described data set. Less than half (42 percent) of all female work observed was indoors, a proportion not so different from that of male work (37 percent). The sexual division of labour was more flexible than has often been thought, or than contemporary published opinion approved. In agriculture, especially, women made up an unexpectedly high percentage (nearly a third) of the observed labour force. In guilded crafts, in contrast, women were almost completely absent. This finding directed attention to gender-discrimination by social institutions, rather than gender-specific biological characteristics, as the fundamental variables in explaining variations in the sexual division of labour.

This is an example of a simple, factual finding that would be practically impossible to discern by simply immersing one's self in the church court records. It would be as difficult to do this as it would to find a mortality rate by immersing one's self in parish registers. And the improvement in understanding of the society is of the same nature as those expounded by Wrightson above for the use of quantitative illegitimacy and bridal pregnancy ratios as a control on qualitative statements about sexual conformity. Of course the real power of such controls becomes fully evident only when one advances beyond simple factual findings of this kind to the study of why these facts obtained, and what their larger consequences might have been. Here the availability of solid ground under one's feet - a backdrop of well-defined, often measurable ad-hoc empirical categories - enables us to extend the rigorous analysis hitherto reserved to demographic questions about households, migration, labour markts, and servanthood to questions about the sexual division of labour and restrictive local institutions.

\section{Prospects for the Micro-Exemplary Method}

If we step back and look at the micro-exemplary method in a larger perspective, its power and sweep may seem less surprising. Stripped to its purely structural features, the micro-exemplary method is really very simple and classical. It consists essentially in upholding a distinction between a historical meta-language and the object language of the society under study. It consists in the commitment to maintaining both these perspectives. It amounts to an anti-reductionism; the refusal either to follow the (historicist or ethnomethodological) recommendation to sacrifice the sober, science-informed thirdperson perspective of our objectivity-aspiring meta-language or to follow the (cliometric) suggestion that we sacrifice our qualitative, holistic, first-person understanding of the object language we are studying. The main features of the micro-exemplary method described above are simple consequences 
of this dual commitment. Since neither meta-language nor object language is reducible to the other, in the micro-exemplary view, they must co-exist in dialectical interchange. And since the purposes of history are many, it is best to constitute our basic meta-language, at the outset, with concepts that are as close to the data, as neutral and "natural" as possible. This will maximize the usability of these concepts for the wide variety of different theoretical perspectives that the different users of history (practical, ideological, scientific) will want to apply.

The only other assumption from which the micro-exemplary method proceeds is a practical constraint: the recognition that the historian is in the peculiar situation of being utterly dependent on data. More than any other kind of intellectual worker, the historian has to make the data her starting point. Of course when she immerses herself in her data, she brings all her theoretical interests, her ideological prejudices and political pre-conceptions, her first-hand knowledge of her own and other societies, all her reading and her ignorance, to the table. These are her privilege: they give her questions to ask of the data - the more the better, as she will soon find, upon immersion, that the data are highly uncooperative. They reject most questions out of hand, and they frown on all questions. There is almost never a smooth fit between a question or hypothesis one entertains going in and the documents one encounters. Immersion in data is like any confrontation with a new and foreign culture; it requires adjustment, reorganization of one's categories, recognition that there are ways of thinking and feeling that are recognizeably human but different from those one was socialized into by one's own upbringing. So it is simply a failure to note the peculiar constraints of historical research to insist, as Karl Popper and his followers sometimes did, on the need to begin with an explicit theory.

There is nonetheless a germ of truth in Popper's rejection of mere fact-gathering empiricism. ${ }^{136}$ The slogan of "total history", as propagated by the second-generation Annales school, was briefly fashionable, but the danger of achieving nothing more than a shapeless mound of meaningless data bits, a kind of archival core dump, soon became apparent. ${ }^{137}$ It is clear that history cannot be neutral, comprehensive description, but must always answer some directed question. And the most natural context for such questions to arise is that of immersion in documents. Not that the documents themselves could somehow suggest the questions, or that a mechanical pasting together of facts from a

\footnotetext{
${ }^{136}$ As expressed, for instance, in his Logic of Scientific Discovery, 2nd edition (London: Hutchinson 1968), p. 280; also Popper, "Logic of the Social Sciences".

${ }^{137}$ Wrightson, "Villages, Villagers, and Village Studies", p. 634, who also refers to remarks by Quentin Skinner ("The Role of History" Cambridge Review March 1974, p. 102) to indicate the wider disillusionment with the idea. See also Medick, Weben und Überleben, Chapter 1.
} 
series of documents could even so much as guide the historian to a sense of what was worth asking. The historian's questions come, rather, from whatever she brings to the process to begin with. Her own questions and preoccupations will always at least partly determine what appears to her as an internal discrepancy, or what seems to distinguish this society from others she knows. Only the dialectical process of quantitatively testing the view that results from qualitative immersion in documents, revising that view, re-testing it, and revising it again (and so on) anchors the intuitive "feel" for the society in a more intersubjective realm of public discourse.

The historian's starting point, then, is neither within the historical meta-language she ultimately wants to use nor in the object language (which at this early stage is still largely foreign). The formation of her meta-language results, rather, from a dialectical process of inquiry, whose first step is the culture clash between the historian's own socialization, her own categories, and those of the documents she confronts. From this first encounter she begins to learn some of the vocabulary, and perhaps part of the grammar, of the object language. She isn't very fluent yet, there are many gaps. But it is enough to reveal discrepancies, to raise questions. And so she can begin to try to test some of her hunches by systematizing the qualitative data into a rough and ready meta-source.

By means of this systematization, the historian begins to construct the first, rudimentary components of an appropriate meta-language. But in doing so she must maintain a certain distance; she must step back from her particular, immediate guesses and questions, she must restrain herself from catering to them exclusively. She must keep in mind that she will also have future questions, that she is working, ultimately, toward a standpoint, expressed in the meta-language, that integrates her future, more fluent knowledge of the object language with some version of the impersonal, scientific standpoint that represents her aspiration toward objectivity. ${ }^{138}$ The extraction of quantitative from qualitative data is the first step in this dialectic, and the aspiration to objectivity is reflected in the striving to keep the

\footnotetext{
${ }^{138}$ We regard the dialectical process described here to be one whose outcome is the replacement of the vague intimations one began with, in one's initial immersion in the object language, by a more comprehensive and informed view in the metalanguage that does justice to - is informed by - everything learned through that immersion. That is the sense in which a narrower "subjectivity" is replaced by a wider perspective of "objectivity", but there is no assumption that the viewpoint attained is a "true" or "correct" one, from some imagined ultimate viewpoint of objectivity; there is only more and less. We assume (see next footnote) that although one's initial immersion is “theory”-dependent (guided by one’s prejudices, prior knowledge, etc.), there is no way of knowing what that "theory" is other than by using it, trying it out in the process of inquiry. In trying to see how their world looked to the people who generated those documents, one's "theories" are being changed by the process of immersion. One tries to think and feel one's way into that foreign way of seeing things, then one has questions. The important thing is that those questions be precise (that the meta-language be sufficiently precise); that is the way to cross-check one's initial view and begin, step by step, to anchor it in a public discourse, a wider view.
} 
categories of the resulting "meta-source" as neutral, as immanent, and as close to the data as possible, to leave open the possibility of asking things in future that were not thought of in advance.

This desideratum is in obvious tension with the question-drivenness of the original immersion in documents. But it is equally indispensable, because the particular aspect of the society focussed on to begin with has to be seen in the wider context of the functioning of the entire society, which only results from dialectical iterations and the mutual feedback of the qualitative immersion and quantitative testing. This does not mean reconstructing the entire society (in "total history" fashion), but it means that the data gathered in response to the original questions should not be usable solely for answering those particular questions. ${ }^{139}$ Evidence can never, of course, be completely theory-neutral, but we should do our best to make it as neutral as possible under the given conditions. ${ }^{140}$ We should aim for empirical robustness, as in the example of the household literature. Otherwise we cannot hope to recover the wider social, institutional, and economic context of the particular phenomenon we are interested in studying, we cannot see it in three dimensions.

The micro-exemplary requirement that the investigation focus on a relatively small community is an immediate consequence of the need to balance these first two desiderata of the method (questiondrivenness of the initial immersion and neutrality in compiling the meta-source), in the context of dialectical iteration between qualitative immersion and quantitative testing. If the extraction of quantitative from qualitative data is - on the one hand - to be driven by questions, but also - on the other hand - in a way that makes it possible to study the wider social and institutional context of this question, then an upper bound is set on the size of the community it is practically possible for a single researcher (or even a small group) to study in a limited number of years. It is not clear exactly where this limit lies, and perhaps it varies with different kinds of study and with the technology available to the historian, but to judge from existing community studies, it seems it is somewhere around five thousand.

\footnotetext{
${ }^{139}$ This, again, is why the early efforts at (pre-database) record-linking software sought to be as flexible as possible in the way they stored data and enabled it to be accessed; see above, note 44.

${ }^{140}$ In the long-running debate about the "theory-dependence" of observational evidence, following N.R. Hanson's revival of Duhem's famous point that "it is impossible to leave outside the laboratory door the theory we wish to test" (P. Duhem, The Aim and Structure of Physical Theory, transl. by P. Wiener (Princeton, NJ: Princeton University Press), p. 182), most participants agree that theory-neutral evidence is impossible. But in nearly all this literature, such "theory-dependence" is regarded as either present or absent, not as a matter of degree. And yet in most practical contexts it is regarded as a matter of degree - and as improvable by appropriate interventions. Law courts, for instance, accept that evidence is inevitably somewhat tainted by the particular viewpoint of the witness, and corroborating evidence is required in most cases. There is no standard of complete or final objectivity in establishing questions of fact, only better and worse. This, it seems, is also the attitude implicitly adopted in practice (though less consistently in their theoretical pronouncements) by most historians.
} 
For the kind of reasonably well-documented community needed for such research even to be feasible, a larger community would have too many documents for even a reasonable cross-section to be sampled within a few years to the extent that a coherent "feel" for the workings of the community could begin to emerge as a basis for quantitative cross-checking. ${ }^{141}$

How "close to the data" a concept is, and how "naturally" it lends itself to counting, are practical matters, and matters of degree, as we saw, not of kind (let alone of ontological taxonomy). The concept of "illegitimacy ratio" obviously has no meaning in a society that lacks a stably defined institution of marriage, and as we saw above, there are differences among societies in their definition of "household", which can make even the most straightforward household classification scheme appear problematic. So even the most apparently "empirical" or "natural" category or concept is to some degree an imposition; short of total historicism or ethnomethodology the ideal of a perfect fit between our categories and the data is illusory. And the creation of a meta-source for studying a particular community will always be somewhat ad hoc; there is no way of knowing in advance which concepts will endure in the course of a research project and which will ultimately be winnowed out. It is only by proposing concepts (or a classification system, or a set of categories) that seem "natural” for some particular, given set of documents from a particular community, and then using them, that progress can be made. It is only against some defined set of existing classifications that researchers for other communities in other parts of the world can discover that some tentative classification does not work in their case. So the true ultimate potential of the micro-exemplary method lies in the number and variety of studies that use it. However interesting and valuable any particular study might be, it is in their cumulative contribution that the real value of micro-exemplary studies lies. ${ }^{142}$

\footnotetext{
${ }^{141}$ Our figure for the maximum feasible community size assumes a highly multi-stranded society of the kind one would expect to find in early modern continental (especially cental, southern, or eastern) Europe, or in many parts of present-day less-developed countries. In modern European or more developed Asian countries, relations are more single-stranded, so the number of links among individuals is normally much lower. This would then mean that, depending on the kind of group or "community" studied, the maximum population in a micro-exemplary study of a modern society could be much larger than 5,000. Gidon Cohen and Kevin Morgan, for instance, applied something very like the micro-exemplary method in their study of the Communist Party of Great Britain, with a total population of around 20,000 in their database; see their "Stalin's Sausage Machine: British Students at the International Lenin School 1926-37", Twentieth-Century British History 13 (2002), pp. 327-55. The relevant upper constraint, then, is not the population size but the number of links.

142 There is therefore a crucial role to be played by studies that juxtapose and appraise the results of numerous microexemplary projects. A good example of this is Josef Ehmer's brilliant synthesis of a number of detailed local studies with the theories of early modern German intellectuals and bureaucrats on the necessity for the early modern state to control access to marriage and full economic rights by "economically and morally weak persons" in his Heiratsverhalten, Sozialstruktur und ökonomischer Wandel: England und Mitteleuropa in der Formationsperiode des Kapitalismus (Göttingen 1991).
} 
Meanwhile, though, each individual micro-exemplary study has no choice but to do its own laundry; it has to go as far as it can toward ensuring that its data are internally consistent. Studies that employ a single source over a long period, for instance, can usually determine whether the generating process underlying that source is uniform, in relevant respects, over the period studied. From the qualitative immersion in the documents it should be clear whether the institution or social group generating the documents in question changed in any way over the period in question, and whether such changes would have been likely to affect the consistency and comparability of the information produced over that period. If there were such changes, then either the period for which the quantitative data is extracted is changed to fit, or further cross-checks can be undertaken to be sure that the changes introduce no systematic biases of relevance to the questions being asked. (Obviously this needs to be reconsidered each time these same data are to be used to answer a new kind of question.) Usually changes of this kind are not obvious one-time changes but evolve over time. One kind of change that may affect the consistency over time of the information from a data source is volume. A court that hears ten cases per month may well change its procedure (and thus the information content to be gleaned from its records) if this increases to a hundred cases per month. Cultural changes may affect the emphasis of courts whose main interest is social control (such as church courts). Even the quality of information from parish registers can be affected if, for instance, there is a gradual change (or a change from one parish scribe to the next) in the recording of illegitimate births, emergency baptisms, or circumnatal deaths. Often such changes can be controlled for, and quantitative data from the series of sources can still be used; they can still act as an external control on the subjective impression the historian gets from qualitative immersion. But it is important to be aware of such changes, so that if the data are to be applied to a question where the shift is of relevance, appropriate cross-checks are applied, and an appropriate degree of scepticism attaches to the results.

In these and other ways, the meta-source compiled for a particular community can be tested for reliability and representativeness, to ensure that the quantitative cross-checks on the historian's initial, subjective response to the sources in their qualitative aspect are as robust as possible. Of course no amount of Quellenkritik will ever guarantee that the data are absolutely reliable, just as no particular observation in biology or physics can ever be taken as ironclad; we are not dealing in certainties. And in history - why deny it? - we are considerably less certain than in theoretical sciences. History is messy. But this is no more reason than in medicine not to try to do as well as we can. Applying quantitative cross-checks to our qualitative, hermeneutic, holistic grasp of the documents minimizes our chances of going drastically wrong. 
The good news is that once we have established a meta-source with a reasonably high degree of internal consistency (as well as external consistency with other, comparable communities), we can then leverage the robustness and reliability achieved and "transmit" it, so to speak, to other databases, like the work database used in the study of gender-specific work patterns discussed above. The (by now) age-old technique of turning qualitative into quantitative evidence (and using them in dialectical feedback with each other) can thus be greatly expanded, it turns out, far beyond the relatively narrow confines of "naturally" countable sources. Quantitatative data, it transpires, can be generated even from the most "purely" qualitative data (like court records), and can parasitically draw the reliability and robustness they need (to function as an effective cross-check on qualitative immersion) from a meta-source compiled from more "naturally" countable sources. If these cross-checks confirm the reliability of the new meta-source, then they also, of course, give additional support to the trustworthiness of the "naturally" countable sources; the support gained is mutual, if (as in the Wildberg case) the data come from mutually independent sources.

Even without the vast perspectives opened up by this new extension of the micro-exemplary method, the more basic use of the method has brought enormous progress to the study of past societies in England, Germany, Switzerland, and other parts of Europe. But the prospect of using what had seemed purely qualitative sources to generate quantitative data vastly increases the possible applications of the micro-exemplary method. It suggests that a much wider range of issues could be addressed by this method than has ever been thought possible. There has of course never been any reason why it could not be applied to societies outside Europe, and in later periods than the pre-industrial, such as the longrunning debate about the impact of the Industrial Revolution on the standard of living, the origins of the nineteenth-century demographic transitions in France and England (and the twentieth-century ones elsewhere), or how quite different institutional systems in non-European societies affected the process of economic growth and the distribution of its gains. The new possibilities offered by turning a wider range of purely qualitative evidence into quantitative evidence, though, extends this list far beyond the scope of what has traditionally been considered "social and economic history" to almost any imaginable sphere. ${ }^{143}$ The "community" to be studied in micro-exemplary style need not be a physical community, in the traditional sense. It can also be an ethnic community in a modern city, a nineteenth-century

\footnotetext{
${ }^{143}$ Like any other approach, this one, too, would eventually come up against limits. Its great advantage clearly lies in the depth it gives an investigation; where breadth is needed, other methods are needed. Our message here is that it is much too soon to say where the limits of the micro-exemplary approach might ultimately lie; only trial and error can give the answer.
} 
university, a scientific discipline, a government department, a business corporation, or, to cite a specific example that has recently been studied in something like a micro-exemplary style, the prosopography of the Communist Party of Great Britain. ${ }^{144}$

The only obstacle to the much more widespread use of the micro-exemplary method to address such questions is the narrowness imposed by the disciplinary organization of the social sciences. The two perspectives to which the micro-exemplary method is fundamentally committed reside in different disciplines, and there is presently no single discipline that rewards the very labour-intensive conjunction of them required by the micro-exemplary method. The holistic immersion in qualitative data is the province of history and anthropology, while the collection and statistical manipulation of quantitative data is the province of economics, econometrics, and social psychology. (Some social sciences, such as sociology, geography, and political science, are split.) Weber's hope for a fusion of these two perspectives is realized in the micro-exemplary method, but the vast majority of historians and economists are contented within the self-imposed restriction to only one of these two. It is to be hoped that a sufficiently large minority on both sides can overcome these barriers. The rewards are great. And if our institutional limitations can be overcome, there is every reason to believe that, for all its achievements so far, the micro-exemplary approach is still in its infancy.

\footnotetext{
${ }^{144}$ G. Cohen and K. Morgan, "Stalin’s Sausage Machine”. The authors have also come to methodological conclusions remarkably similar to those set forth in this paper; see their working paper G. Cohen, A. Flinn, and K. Morgan "Toward a Mixed-Method Social History: Combining Quantitative and Qualitative Methods in the Study of Collective Biography", delivered at the ESSH conference, Berlin, March 2004; G. Cohen, "Missing, Biased, and Unrepresentative: The Quantitative Analysis of Multi-Sourced Biographical Data”, Historical Methods 35 (2002), pp. 167-177 discusses some of the technical challenges peculiar to such an approach.
} 